\title{
Mu'tezile’de Ma‘dûm Anlayışı: Ebû Reşîd En-Nîsâbûrî Örneğinde Bir İnceleme
}

\author{
Muzaffer Barlak \\ Dr. Öğr. Üyesi, Sinop Üniversitesi Illahiyat Fakültesi (ROR ID: 004ah3r71) \\ Kelam ve İslam Mezhepleri Tarihi Anabilim Dalı \\ Assistant Professor Dr., Sinop University Faculty of Theology, Department of Theology and History of Islamic Sects \\ Sinop/Turkey \\ mbarlak@sinop.edu.tr \\ ORCID: 0000-0001-9086-4379
}

\section{The Concept of Ma'dûm (i.e. Non-existent) in Mu'tazila: A Review on Abū Rashīd āl-Nīsābūī}

\begin{abstract}
"Ma'dûm" is a concept used to mean "non-existent". Schools of Kalām have studied the nature of non-existent around the ma'dûm concept. In this context, it was discussed what happened before the things exist. The movement that first started this debate in the Kalām was Mu'tazila. According to Mu'tazila, ma'dûm is not absolute non-existent; in contrast, it is a "thing". This view of Mu'tazila was rejected by the Ash'ariyyah and Māturīdiyyah. Not only did the Ash'ariyyah and Māturīdiyyah scholars rejected the view of Mu'tazila in this regard, but also formed their own view on the issue. According to this view, ma'dûm is not a "thing", in the contrast, it is absolute non-existent, in other words, it is nothing. Almost all of the Ahlal-Sunna accepted this view. These two different approaches on ma'dûm were the distinguishing qualities of both Mu'tazila and Ahl-al-Sunna.

It is possible to argue that both views, which contrasted each other, developed with certain concerns. The main concern of Ahl-al-Sunna, which advocates the view of "ma'dûm is absolute non-existent", is not to harm the idea that Allah is a single eternal entity. As a matter of fact, if ma'dûm is accepted as a "thing" instead of absolute non-existent, it will be said that there is another entity that has existed with Allah since the eternity, which will damage the idea that Allah is the only eternal being. The main concern of Mu'tazila, who advocated the view that "non-existent" is a "thing", was to purify Allah's knowledge from all kinds of flaws and deficiencies. As a matter of fact, if ma'dûm is accepted as an absolute non-existent, not a "thing", Allah will only know what he will create after he has created them, which will damage the idea that Allah has known everything perfectly since the eternity, and will undermine Allah's omniscience attribute.

The one that belongs to Ahl-al-Sunna from these two approaches about whether ma'dûm is absolute non-existent or a "thing", was discussed by many Sunni thinkers in detail. However,
\end{abstract}

İntihal Taraması/Plagiarism Detection: Bu makale intihal taramasından geçirildi/This paper was checked for plagiarism Geliş/Received: 02 Temmuz/July 2020 |Kabul/Accepted: 14 Ağustos/August 2020|Yayın/Published: 20 Eylül/September 2020 Atıf/Cite as: Muzaffer Barlak, "Mu'tezile'de Ma‘dûm Anlayışı: Ebû Reşîl En-Nîsâbûrî Örneğinde Bir İnceleme = The Concept of Ma'dûm (i.e. Non-existent) in Mu'tazila: A Review on Abū Rashīd āl-Nīsābūrī", Eskiyeni 41 (Eylül/September 2020), 653-678. https://doi.org/10.37697/eskiyeni.763019

Copyright @ @ Anadolu İlahiyat Akademisi/Anatolian Theological Academy, 06050, Ankara, Turkey | www.anilakademi.com CC BY-NC 4.0 | This paper is licensed under a Creative Commons Attribution-NonCommercial License 
it is seen that the one that belongs to Mu'tazila does not have adequate clarity. As a matter of fact, considering the works of their own scholars, it is understood that the ma'dûm, which Mu'tazila described as a "thing", carries an epistemological nature, not an ontological nature. The position of this epistemological truth is considered as Allah's eternal knowledge. In this case, both of the ideas of Allah knows everything with His knowledge, and that Allah is the only eternal being are not harmed.

One of the thinkers who can be referred to on Mu'tazila's ma'dûm understanding in the framework of their own resources is Abū Rashīd āl-Nīsābūrī, who conveyed the different approaches of Mu'tazila about ma'dûm, and then explained his opinion on this issue in detail in his book al-Masā’il fi l-khiläf bayn al-bașriyîn wal-baghdādiyîn (Questions concerning the differences between the Bașrah and Baghdad). There are two important points that come to the forefront in the non-existent view of Āl-Nīsābūrī. The first one is that ma dûm is considered as a "thing", not an absolute non-existent; and the second is the claim that ma'dûm has no physical entity, but that it has a presence in the mind. Over these two emphases, it can be speculated that two issues related to maddûm are resolved. In this respect, it is stated that there is nothing that Allah does not know about in the eternity by saying that ma'dûm is not absolute non-existent. With this acceptance, the knowledge of Allah is cleared of all kinds of deficiencies. When the idea that ma'dûm is a mental entity, not a physical one is accepted, the idea that Allah does not have equal is not damaged. As a matter of fact, an entity in the form of knowledge is nothing other than Allah, but it is a being that is the requirement of Allah. Because Allah is the one who is All-Knowing.

Āl-Nīsābūrī evaluated the ma dûm as a "thing" in terms of its being the substance/essence, being known and being eternal. According to him, the substance should exist even in case of the non-existent of it. Since substance is substance in case of its non-existent, then it is maddûm, i.e. an substance. Since there is nothing beyond the knowledge of Allah, madûm consists of the "known". Being known requires being separated from other things with a clear attribute. Therefore, ma'dûm is a "thing" with a distinct attribute. Since ma'dûm is a "thing", and since it is in the knowledge of Allah since the eternity, then it is also eternal.

\section{Keywords}

Kalām, Mu’tazila, Nīsābūrī, Ma‘dûm, Known, Non-existent

\section{Mu'tezile'de Ma'dûm Anlayışı: Ebû Reşîd En-Nîsâbûrî Örneğinde Bir İnceleme Öz}

Ma‘dûm, yokluk anlamında kullanılan bir kavramdır. Kelam ekolleri, ma‘dûm kavramı etrafinda yokluğun mahiyetini inceleme konusu yapmışlardır. Bu kapsamda var olan şeylerin, var olmalarından önce ne oldukları tartışılmıștır. İslâm Kelâmında bu tartışmayı ilk olarak ortaya çıkaran akım, Mu'tezile'dir. Mu'tezile'ye göre ma‘dûm, mutlak yokluk değildir; bunun aksine o, bir “şey”dir. Mu'tezile'nin bu görüşü, Eşsariyye ve Mâtürîdiyye tarafından reddedilmiştir. Eş‘ariyye ve Mâtürîdiyye düşünürleri, Mu'tezile'nin bu konudaki görüşünü reddetmekle kalmamış, konu ile ilgili kendi görüşlerini de oluşturmuşlardır. Bu görüşe göre ma‘dûm, bir "şey" değil, aksine mutlak yokluk, yani hiçbir şeydir. Ehl-i Sünnet'in neredeyse tamamı bu görüşü kabul etmiştir. Ma‘dûm konusundaki bu iki farklı yaklaşım, gerek Mu'tezile'nin, gerekse Ehl-i Sünnet'in ayırt edici vasıflarından olmuştur.

Birbirine zıt olarak ortaya konulan her iki görüşün de, belli kaygılar eşliğinde geliştirildiğini söyleyebiliriz. "Ma‘dûm, mutlak yokluktur” görüşünü savunan Ehl-i Sünnet’in temel kaygısı, 
Allah'in tek ezelî varlık olduğu düşüncesine zarar vermemektir. Nitekim şayet ma'dûm, mutlak yokluk değil de bir "şey” olarak kabul edilirse, Allah ile birlikte ezelden beri var olan başka bir varlığın daha bulunduğu söylenmiş olacaktır. Bu ise Allah’ın tek ezelî varlık olması düşüncesine zarar verecektir. "Ma‘dûm, bir “şey"dir” görüşünü savunan Mu'tezile’nin temel kaygısı ise, Allah'ın bilgisini her türlü kusurdan ve eksiklikten arındırmaktır. Nitekim şayet ma‘dûm, bir "şey" değil de, mutlak yokluk olarak kabul edilirse, Allah, yaratacağı şeyleri, ancak onları yarattıktan sonra bilebilecektir. Bu ise Allah'ın ezelden beri her şeyi kusursuz olarak bildiği düşüncesine zarar verecek ve Allah'ın ilim sıfatını noksan hale getirecektir.

Ma‘dûmun mutlak yokluk mu yoksa bir "şey" mi olduğu konusundaki bu iki yaklaşımdan Ehl-i Sünnet'e ait olanı, birçok Sünnî düşünür tarafından ayrıntılı olarak ele alınmıştır. Ancak Mu'tezile'ye ait olan kanaatin yeterince açıklık kazanmadığı görülmektedir. Nitekim kendi düşünürlerine ait eserler dikkate alındığında, Mu'tezile’nin “şey” olarak nitelediği ma dûmun, ontolojik bir mahiyet değil, epistemolojik bir mahiyet taşıdığı anlaşılmaktadır. Bu epistemolojik hakikatin makamı ise, Allah'ın ezelî bilgisi olarak değerlendirilmektedir. Bu durumda hem Allah'ın ezelî ilmi ile her şeyi bildiği, hem de Allah'ın tek ezelî varlık olduğu düşüncelerinin ikisine de zarar verilmemiş olmaktadır.

Mu'tezile'nin ma'dûm anlayışının kendi kaynakları çerçevesinde ele alınması noktasında eserlerine başvurulabilecek düşünürlerden biri, Ebû Reşîd en-Nîsâbûrî̉dir. Ebû Reşî̀d en-Nîsâbûrî, el-Mesâ'il fil-hilâf beyne'l-Bașriyyîn ve'l-Baǵdâdiyyîn adlı kitabında ma'dûm ile ilgili Mu'tezile'ye ait farklı yaklaşımları aktarmış ve ardından kendisinin bu konu ile ilgili düşüncesini ayrıntılı olarak açıklamıştır. Ebû Reşîd en-Nîsâbûrînin ma'dûm görüşünde öne çıkan iki önemli nokta bulunmaktadır. Bunların ilki, maddûmun, mutlak bir yokluk olarak değil, bir "şey" olarak kabul edilmesi; ikincisi ise ma dûmun, bedenî bir varlığının bulunmadığının ama zihinde bir varlığının bulunduğunun ileri sürülmesidir. Bu iki vurgu üzerinden maddûm konusu ile ilgili iki sorunun çözülmeye çalışıldığı ifade edilebilir. Buna göre ma‘dûmun, mutlak yokluk olmadı̆̆ının söylenmesi sayesinde Allah'ın ezelde bilmediği bir şeyin bulunmadığı ifade edilmiş olmaktadır. Bu kabul ile Allah'ın ilmi, her türlü kusurdan arındırılmaktadır. Ma‘dûmun, bedenî değil, zihnî bir varlığının bulunduğunun kabul edilmesi sayesinde ise, Allah'ın şerikinin/ortağının bulunmadığ düşüncesine zarar verilmemiş olmaktadır. Nitekim bilgi mahiyetindeki bir varlık, Allah'tan başka bir varlık değil, aksine Allah’ın zâtının gereği olan bir varlıktır. Çünkü Allah, ezelî olarak âlim/bilendir.

Nîsâbûrî, ma'dûmun "şey” oluşunu, onun cevher/öz olması, malum/bilinen olması ve ezelî olması açısından değerlendirmiştir. Ona göre cevherin, yokluğu halinde de cevher olması gerekir. Mademki cevher, yokluğu halinde de cevherdir; o halde ma‘dûm, cevherdir. Allah'ın bilgisinin dışında bir şey olmadığına göre mađdûm, malum/bilinenden ibarettir. Biliniyor olmak, belirgin bir sifat ile diğer şeylerden ayrışmış olmayı gerektirir. O halde ma‘dûm belirgin sıfatı bulunan bir "şey"dir. Mademki ma‘dûm bir şeydir ve mademki ezelden beri Allah'in bilgisindedir, o halde o da ezelîdir.

\section{Anahtar Kelimeler}

Kelam, Mưtezile, Nîsâbûrî, Ma‘dûm, Ma'lûm, Yokluk

\section{Giriş}

Ma'dûm, sözlükte yokluk, var olmamak, hiçlik gibi anlamlarda kullanılmaktadır. ${ }^{1}$ Kelâmî bir terim olarak ma'dûmun anlamı ise her bir düşünürün konuya ilişkin

1 İbn Manzûr, Lisanül-Arab, thk. Abdullah Ali Kebir vd. (Kahire: Dâru'l-Maarif, ts.), 4/2842-2843. 
kanaatine göre farklılık göstermektedir. Bu farklılıklar eşliğinde ma'dûmun ne olduğu ile ilgili farklı açıklamalar ortaya çıkmıştır. ${ }^{2}$ Bu açıklamalarda ma'dûm, bazen Allah'tan başka bütün varlıkların ihdâs edilmelerinden önceki durum ${ }^{3}$, bazen aklen muhal olanlar ${ }^{4}$, bazen bir şey olmayan ${ }^{5}$, bazen de varlığı herhangi bir yetenek veya duyu yoluyla hissedilmeyip akılla da düşünülemeyenler şeklinde tanımlanmıştır. ${ }^{6}$ Kelam düşünürleri, ma‘dûm tanımlarını ortaya koyarken, bu seçeneklerin birini esas alabildikleri gibi birkaçını bir araya toplayarak da ma'dûm tanımı yapabilmiştir. Bu içeriklerden hangisinin ya da hangilerinin ma'dûm olarak kabul edileceğini belirleyen ana unsur ise, tanımı ortaya koyan düşünürün konuya ilişkin kanaati olmuştur.

İslâm kelâmında ma‘dûm ile ilgili tartışmaları ilk olarak gündeme getiren akım, Mu'tezile'dir. Ma'dûm kavramı etrafında tartışılan problem ise, temelde ma'dûmun "şey" olup olmadığı hakkındadır. Ma'dûmun bir "şey" olduğu görüşünü Mu'tezile, “şey” olmadığı görüşünü ise, Mu'tezile’ye tepki mahiyetinde Ehl-i Sünnet temsil etmektedir. ${ }^{7}$ Ma'dûm ile ilgili bu iki yaklaşım, Ehl-i Sünnet ve Mu'tezile'nin ayırt edici özelliklerindendir. ${ }^{8}$ Ma'dûm hakkındaki tartışmaların "şey" kavramı üzerinden yürütülmesinde Kur'an kaynaklı bir bakışın etkili olduğu da söylenebilir. ${ }^{9} \mathrm{Ni}$ tekim ma'dûm kelimesi Kur'an'da yer almamaktadır; ancak ma'dûma işaret edecek mahiyette iki ayette şöyle buyurulmaktadır:

"İnsanın üzerinden, henüz kendisinin anılan bir şey olmadığı uzun bir süre geçmedi mi?"10

"O insan kendisi önceden bir şey değilken onu yaratmıs olduğumuzu düşünmez mi?"11

Bu ayetlerde geçen "(henüz var olmayan) şey” ifadesinin anlam alanı, ma'dûm tartışmalarına önemli bir referans değer oluşturmaktadır. Bu ifadenin anlamının iki şekilde düşünülmesi mümkündür. Bunların ilki, hiçbir şey olmayan mutlak yokluk;

2 R. M. Frank, "Al-Ma'dūm wal-Mawjūd the Non-Existent, the Existent and the Possible in the Teaching of Abū Hāshim and His Followers", Mélanges Institut Dominicain D'études Orientales (MIDEO), 14 (1980), 185.

3 Kâdî Abdülcebbâr, Ebu'l-Hasan el-Hemedânî. Şerhu'l-Usûli'l-Hamse, thk. Abdulkerim Osman (Kahire: Mektebetü Vehbe, 1996), 176.

4 Seyfüddin el-Âmidî, Ebkâru'l-Efkâr fî Usûli'd-Dîn, thk. Ahmed Muhammed el-Mehdî (Kahire: Dâru'l-Kütüb ve'l-Vesâiki'l-Kavmiyye, 2004), 3/379.

5 İbn Fûrek, Mücerradü Makalâti'ş-Şeyh Ebil-Hasan el-Eş‘arî, nşr. Daniel Gimaret (Beyrut: Dârü'l-Maşrık, 1986), 252; Ebû Bekr el-Bâkıllânî, Kitâbü Temhîdi'l-Evâil ve Telhîsü'd-Delâil, nşr. İmâdüddîn Ahmed Haydar (Beyrut: Müessesetü'l-Kütübi's-Sekâfiyye, 1993), 35.

6 Ebû Mansur el-Mâtürîdî, Kitâbü’t-Tevhîd Tercümesi, çev. Bekir Topaloğlu (İstanbul: İsam Yayınları, 2005), 110.

7 Yusuf Şevki Yavuz, “Adem”. Türkiye Diyanet Vakfi İslâm Ansiklopedisi. (İstanbul: TDV Yayınları, 1988), $1 / 356$.

8 Hülya Alper, “Yokluk Nedir? Seyfeddin El-Âmidî'de Ma‘dûm Kavramı Üzerine Bir İnceleme”, İstanbul Üniversitesi İlahiyat Fakültesi Dergisi 28 (2013), 36.

9 “Şey” kavramının Kur'an'da işlenişi ile ilgili olarak bakınız: Robert Wisnovsky, “İbn Sînâ’nın Şey “iyye Kavramı Üzerine Notlar” çev. Arzu Meral, Marmara Üniversitesi İlahiyat Fakültesi Dergisi 26/1 (2004), 85-118.

10 el-İnsan 76/1.

11 Meryem 19/67. 
ikincisi ise varlı̆̆ 1 da yokluğu da mümkün olan bir mahiyet veya "şey" şeklindedir. ${ }^{12}$ Bu iki tanım aslında sırasıyla Ehl-i Sünnet ve Mu'tezile’nin, ma‘dûmun "şey” olması veya olmaması ile ilgili yaklaşımlarını da yansıtmaktadır. Zira Ehl-i Sünnet'e göre ma'dûm "şey" değildir; ama Mu'tezile'ye göre "şey"dir. ${ }^{13}$ Aslında bu iki seçenek, Allah'ın ilminin ma'dûm ile ilişkisine dair iki farklı bakış açısına zemin hazırlamaktadır. Ancak her iki bakış açısı için de önemli itiraz noktalarının bulunduğunu ifade etmek gerekir.

İlk seçenekte yer aldığı şekilde şayet ma'dûm, mutlak yokluk olarak kabul edilirse, Allah'ın, olmayan bir şeyi var ettiği ifade edilmiş olacak ve bu sayede Allah'ın tek ezelî varlık olduğu sabit kılınacaktır. Ancak yaratılmışların varlık bulmalarından önceki hâlin mutlak yokluk olduğu düşüncesi, bu varlıkların, Allah'ın ezelî bilgisinde de bulunmamaları düşüncesine kapı aralayabilecektir. Bu ise Allah'ın ezelî bilgisinde değişikliğin meydana gelmesi veya diğer bir ifadeyle Allah'a kusur atfedilmesi şeklinde anlaşlabilecektir. Özetle ma'dûm, mutlak yokluk olarak kabul edildiğinde Allah'ın tek ezelî varlık olduğu sabit kılınmakta ancak Allah'ın ezeli bilgisinin kusursuzluğuna gölge düşürüldüğü izlenimi oluşmaktadır.

İkinci seçenekte yer aldığı şekilde şayet ma‘dûm, mutlak yokluk değil de bir "şey" olarak kabul edilirse, Allah "her şey"i bildiği için bir "şey" olan yokluğu da bilmiş olacak ve bu sayede Allah'ın ezelî ilminin kusursuzluğu sabit kılınmış olacaktır. Ancak bu kez de ezelî olma vasfı Allah'a hasredilmemiş olacak, O'nunla birlikte bir de "şey" olan yokluğun ezelî olduğu ileri sürülerek taaddud-u kudema'ya düşme riski doğacaktır. Özetle ma'dûm, "şey” olarak kabul edildiğinde, Allah'ın ezelî ilmi kusurdan arındırılmış olacak; ancak ezelîlik vasfının sadece Allah'a ait olmadı̆̆ı hissi uyanabilecektir.

Ma‘dûmun keyfiyetine yönelik bu iki seçeneğin, görüş sahiplerinin kendi dinamikleri çerçevesinde ele alınıp değerlendirilmesi, ma‘dûm konusunun gerçekçi bir şekilde anlaşılması için elzem görülmektedir. Ehl-i Sünnet'in bu konu ile ilgili görüşlerinin müstakil çalışmalarda ele alınıp incelendiği görülmektedir. ${ }^{14}$ Ancak Mu'tezile'nin konu ile ilgili kanaatinin, kendi kaynakları çerçevesinde yeterince ele alınıp incelendiğini ifade etmek güç görünmektedir. Mu'tezile'nin ma'dûma yönelik yaklaşımı, daha çok Ehl-i Sünnet düşünürlerinin eserlerinde yer alan aktarımlar üzerinden ele alınıp değerlendirilmiştir. Bu ise Mu'tezilî ma‘dûm anlayışının otantik formunun günümüz araştırmalarına yeterli düzeyde yansıtılamamasına sebep olmuştur. ${ }^{15} \mathrm{Bu}$ çerçevede bi-

12 Metin Özdemir, Allah’n Bilgisinin Ezelîliği ve İnsan Hürriyeti (İstanbul: İz Yayıncılık, 2003), 123.

13 Mâtürîdî, Kitâbü't-Tevhîd, 110.

14 Ehl-i Sünnet'in ma'dûm görüşü hakkında yapılan bazı araştırmalar için bakınız: Alper, "Yokluk Nedir? Seyfeddin El-Âmidî̀de Ma'dûm Kavramı Üzerine Bir İnceleme”, 33-58; Hüseyin Kahraman, "Ma‘dûmun Şeyiyyeti Teorisine Cüveynî̀nin Getirdiği Eleştiriler Ve Bunların Eş‘arî Kelâmı Açısından Değerlendirilmesi”, Kelâm Araştırmaları Dergisi 14/2 (2016), 443-459.

15 Doğrudan Mu'tezile'nin ma‘dûm anlayışına odaklanmış olmasa da Mu'tezile'nin ma‘dûm anlayışına değinen bazı çalışmalar için bakınız: Ebû’l-Alâ Afîfî, "Mu'tezile’nin Ma'dûm Nazariyesi İle İbn Arabî̉nin A‘yân-1 Sâbite Nazariyesinin Karşılaştırılması”, çev. Cağfer Karadaş, Uludağ Üniversitesi İlahiyat Fakültesi 
zim bu çalışmayı yapmadaki gayemiz, bu eksikliği bir nebze olsun gidermek adına Mu'tezile'nin kendi kaynakları dâhilinde ma‘dûm anlayışlarını ortaya çıkarmaya çalışmaktır. Bu gayeye dönük olarak çalışmamızda, son dönem Mu'tezilesi'ndeki önemli isimlerden biri olan Ebû Reşî̀d en-Nîsâbûrî1 ${ }^{16}$ nin ma'dûm görüşünün detaylı bir tahlilini yapmaya gayret göstereceğiz. Bunun yanında Nîsâbûrînin kanaatlerinin daha iyi anlaşılmasına yönelik olarak diğer bazı düşünürlerin görüşlerini de yeri geldikçe aktarmaya çalışacağız.

\section{Ebû Reşîd en-Nîsâbûrînin Ma'dûm Anlayışı}

\subsection{Ma'dûmun Mütehayyız veya Gayr-1 Mütehayyız Olması}

Ma‘dûmun mutlak yokluk olmadığı, aksine bir "şey" olduğu yönündeki görüş, ilkesel anlamda neredeyse bütün Mu'tezile tarafından kabul görse de ${ }^{17}$ ma'dûmun şeyiyyetinin nasıllığı konusunda Mutezilî bir uzlaşının bulunduğu söylenemez. Bu açıdan ma'dûmun mütehayyı/yer kaplayıcı olduğunun kabul edilmesi veya reddedilmesi, ma'dûmun keyfiyeti ile ilgili Mutezilî ayrılığın belirleyici unsuru konumundadır. Ma‘dûmun şeyiyyetinin nasıllığı konusunda Mu'tezile'nin iki farklı eğilime sahip olduğu görülmektedir. Bunların ilki, ma‘dûmu, "mütehayyız bir şey" olarak kabul etmektedir. İkincisi ise ma‘dûmu, "gayr-1 mütehayyız bir şey" olarak kabul etmektedir. ${ }^{18}$

Mu'tezile içinde maddûmun mütehayyız olduğunu söyleyenlerin bulunduğu bilgisi, diğer Mu'tezilî âlimler ve Ehl-i Sünnet âlimleri tarafından ifade edilmiş olsa da, eserleri elimize ulaşan Mutezilî düşünürler arasında ma'dûmun "mütehayyız bir şey” olduğunu kendi cümleleri ile savunan bir düşünürün bulunduğunu söylemek güçtür. Bu söylemin ancak farklı düşünürlerce Ebû Yakub eş-Şahhâm, Ebû Abdullah el-Basrî ve Ebû İshâk b. Ayyâş gibi bazı Mutezilîlere atfedildiği görülmektedir. ${ }^{19}$

Dergisi 6/6 (1994), 267-276; Orhan Şener Koloğlu, Mu'tezilénin Felsefe Eleştirisi Harezmli Mutezili İbnü'lMelâhimînin Felsefeye Reddiyesi (Bursa: Emin Yayınları, 2010), 204-218; Ömer Ali Yıldırım, "Ma'dûm ve Mümkün: Mûtezile'nin “Ma'dûm” ve İbn Sînâ'nın “Mümkün” Kavramı Üzerine Değerlendirmeler", İslâm Araştırmaları Dergisi 30 (2013), 81-107.

16 Ebû Reşî̀d Saîd b. Muhammed b. Saîd en-Nîsâbûrî, kesin olmamakla beraber h. 630 m. 970 yılı civarında Nişabur'da dünyaya gelmiş, hicrî beşinci yüzyılın ortalarında vefat etmiştir. İlk olarak Mu'tezile'nin Bağdat mezhebine bağlanmıştır. Fakat Kâdî Abdülcebbar ile sık olarak görüşmüş ve ondan ders almıştır. Kâdî Abdülcebbar nezdinde güzel bir kabul görmüş ve onun arkadaşlarından olup Basra Mu'tezilesi'ne dâhil olmuştur. Ebû Reşî̀d en-Nîsâbûrî, Kâdî Abdülcebbar'dan sonra Mu'tezile'nin öncüsü olarak tanıtılmıştır. Nîsâbûrî, Rey şehrinde vefat etmiştir. Ebû Reşî̀d en-Nîsâbûrî, el-Mesâil fil-Hilâf Beyne'l-Basriyyîn ve'Bağdâdiyyîn, Thk. Ma'n Ziyâde, Rıdvan es-Seyyid, (Beyrut: Ma'hedü’l-İnmâi'l-Arabî, 1979), 6-7; Yusuf Şevki Yavuz, "Ebû Reşîd en-Nîsâbûrî", Türkiye Diyanet Vakfi İslâm Ansiklopedisi (İstanbul: TDV Yayınları, 1994), 10/212-213.

17 Ma'dûmun şeyiyyeti konusunda Mu'tezile'nin genel bir kabul içinde olduğu görülse de bazı Mu'tezilî düşünürlerin istisna oluşturduğunu da ifade etmek gerekir. Bu istisnalardan biri, Mu'tezile'nin son dönem temsilcilerinden olan Takiyyüddin Necrânî'dir. Özcan Taşcı, Son Mu'tezile Kelamcısı Takiyyüddin Necrânî (Bursa: Sentez Yayınları, 2013), 163.

18 Nîsâbûrî, el-Mesâil, 37.

19 Fahreddin Râzî, Ana Meseleleriyle Kelâm ve Felsefe el-Muhassal, çev. Eşref Altaş, (İstanbul: Klasik Yayınları, 2019), 51-52; Nîsâbûrî, el-Mesâil, 37; Mâtürîdî, Kitâbü't-Tevhîd, 110-111. 
Bundan dolayı bu tezin hangi argümanlar eşliğinde ileri sürüldügüüü açık olarak ortaya koyma imkânımız bulunmamaktadır. Ma‘dûmun mütehayyız olduğunun ileri sürülmesi, Allah'ın tek ezelî varlık olduğu düşüncesinin savunulmasını güçleştiren bir seçenektir. Buradan hareketle tevhid konusundaki hassasiyeti ile temayüz eden bir mezhebe mensup herhangi bir düşünürün böyle bir kanaati savunmuş olması uzak bir ihtimal olarak görülmektedir. Dolayısıyla bu seçeneğin itham boyutunda, bazı Mutezilî düşünürlere yüklenmiş gerçekçi olmayan veya gereğince anlaşılamayan bir kanaat olduğu da düşünülebilir. Zira elimizde bulunan Mutezilî metinlerde ma'dûmun ancak zihinde bulunan bir varlığa işaret ettiğinin ileri sürüldüğü görülürken, muarızların itirazlarında eleştirilen nokta, Mu'tezile'nin, ma'dûma somut bir varlık hüviyeti atfetmiş olmasıdır. ${ }^{20}$

Mu'tezile içindeki ikinci görüş ise, ma‘dûmun, "gayr-1 mütehayyız bir şey” olduğu şeklindedir. "Gayr-ı mütehayyız bir şey" ifadesini, "varlığı veya yokluğu mümkün olmakla birlikte henüz bedenleşmemiş salt zihnî varlık" olarak anlamamız mümkündür. En azından Mu'tezilî düşünür Ebû Reşî̀d en-Nîsâbûrînin konuya yaklaşımının bu sonuca işaret ettiğini söyleyebiliriz. Nitekim Nîsâbûrî, ma dûm konusunu ele aldığı satırlarda "var olmak" anlamını karşılayacak şekilde "vücûd" ve "husûl" kavramları üzerinde durmaktadır. "Vücûd" derken hem bedenleşmemiş zihnî mahiyetlere hem de bedenleşmiş varlıklara işaret etmekte; "husûl”" derken ise, bedenleşmemiş zihnî mahiyetleri kapsam dışı tutarak sadece bedenleşmiş varlıklara işaret etmektedir. ${ }^{21} \mathrm{Bu}$ kavramsal ayrılık, özelde onun düşüncesinin oturduğu temel hakkında, genelde ise ma'dûm konusundaki Mu'tezilî yaklaşım hakkında fikir vermektedir.

Nisaburînnin hocası olan Kâdî Abdülcebbâr'ın mevcut ve ma'dûm kavramlarıyla ilgili yaklaşımı da bu tespiti güçlendirir mahiyettedir. Nitekim Kâdî Abdülcebbâr'a göre mütehayyız olmak, mevcut olmanın şartı değildir, aksine yer kaplamayan mevcut da vardır. Ma'dûm ise, "mevcut olmayan malum"dur. ${ }^{22} \mathrm{Bu}$ tanıma göre ma'dûm, "hariçte vücudu olmayıp sadece zihinde bulunan varlık" olarak ele alınmıştır. Böyle bir varlığın var olduğunun bilinmesi ise, ancak delil ile mümkün olabilir. ${ }^{23}$ Kâdî Abdülcebbâr'a göre ma'dûmun, malum olması aklî bir gerekliliktir. Çünkü şayet Allah bilmediği şeyi var etmiş olsaydı veya diğer bir ifade ile Allah var ettiği şeyleri ancak var ettikten sonra bilmiş olsaydı, onları düzenli bir şekilde var etmesi mümkün olmazdı. ${ }^{24}$

Hocasının bu konudaki kanaatleri ile paralel olarak Nîsâbûrî de ma'dûm tanımını, malum kavramı üzerinden oluşturmuştur. Nîsâbûrîye göre ma‘dûm, iki çeşit-

20 Râzî, el-Muhassal, 51-52; Mâtürîdî, Kitâbü't-Tevhîd, 110-111; Cüveynî, İmâmu'l-Harameyn. eş-Şâmil fî Usûli'd-dîn, thk. Ali Sâmi en-Neşşâr, Süheyr Muhammed Muhtâr, Faysal Bedir Avn, (İskenderiye: Münşeetü'l-Maârif, 1969), 124.

21 Nîsâbûrî, el-Mesâil, 37-47.

22 Kâdî Abdülcebbâr, Șerhu'l-Usûli'l-Hamse, 176.

23 Kâdî Abdülcebbâr, Şerhu'l-Usûli'l-Hamse, 177.

24 Kâdî Abdülcebbâr, Ebu'l-Hasan el-Hemedânî. El-Muhît bi't-Teklîf, thk: Ömer es-Seyyid Azmî, (Kahire: eşŞeriketü'l-Misriyye, ts.), 125. 
tir. Birincisi, var olmanın yanında yer kaplayıcı olması gerekli olan malumdur. İkincisi ise var olmanın yanında yer kaplayıcı olması imkânsız olan malumdur. İki malumdan her birinin diğerinden ayırt edilmiş olması gerekir. Dolayısıyla iki malumdan her biri, sıfat-1 muntazar (henüz vücut bulmamış olan sıfat) veya sıfat-1 hâsıla (vücut bulmuş olan sıfat) ile ayrışan/temayüz eden olmaktan hâlî değildir. ${ }^{25}$

Gerek Kâdî Abdülcebbâr'ın gerekse Nîsâbûrî'nin ma'dûm tanımlarında iki nokta dikkati çekmektedir. Bunların ilki, ma'dûmun, mutlak bir yokluk olarak kabul edilmemiş olması; ikincisi ise ma'dûmun, bedenî bir varlığının bulunmadığı ama zihnî bir varlığının bulunduğunun ileri sürülmesidir. Bu tespitler üzerinden Mu'tezile'nin ma'dûm konusunu ele almadaki gerekçesini ve ortaya koyduğu görüşe temel teşkil eden kaygısını anlamak mümkün olabilir. Buna göre Mưtezile ma'dûmun ne olduğu ile ilgilenmiştir; çünkü ma'dûmun mutlak yokluk olarak kabul edilmesi, Allah'ın, yarattığı şeyleri, ezelde bilmediği anlamına gelecek, bu ise O'nun ilminde bir kusur olarak nitelenebilecektir. Nitekim şayet ma'dûm, mutlak yokluk ise Allah, mutlak anlamda yok oldukları halde iken varlıkları bilmemektedir. Ne zaman ki Allah o varlıkları var etmiştir, işte o anda Allah'ın ilmine ilave bir bilgi eklenmiş ve ancak bu bilgi ile Allah'ın ilmi tam olmuştur. Şüphe yok ki böyle bir yaklaşımda Allah'ın ilmine değişme niteliği atfedilmiş olur ki bu durum, Allah'ın kusursuz bir varlık olması düşüncesini zedeler. Kanaatimizce Mu'tezile’nin ma'dûm konusunu ele almasındaki temel gerekçe, ma'dûm üzerinden yürütülen tartışmalar çerçevesinde Allah'ın ilmine kusur atfedilmesi endişesidir. Onlar bu konu ile ilgilenmek suretiyle bu endişeyi giderecek bir çözüm arayışına girmiş gibi görünmektedirler.

Mutezilî ma'dûm anlayışındaki ikinci dikkat çeken nokta, yani ma'dûmun bedenî bir varlığının bulunmadığı ama zihnî bir varlığının bulunduğu yönünde ortaya konulan görüş ise, taaddud-u kudema'ya düşmeme kaygısını yansıtmaktadır. Nitekim ma'dûmun yer kaplayıcı bir nitelikte olduğunun ileri sürülmesi durumunda Allah ile birlikte Allah'tan ayrı bir varlık olarak ma'dûmun da kadîm olduğu ileri sürülmüş olacak, bu ise taaddud-u kudema'ya sevk edecek ve tevhid esasını bozacaktır. Ma'dûmun, Allah'tan ayrı bir varlık olarak değil de Allah'ın zâtına ait bir unsur olduğunun kabul edilmesi durumunda ise bu kaygıya yer kalmayacaktır. Çünkü ezelî olan ma‘dûm, artık Allah'tan gayrı bir şey değil, aksine Allah'ta olan bir şeydir. Allah'ın zâtına nisbet edilen herhangi bir hakikat değerinin ezeliyetinde ise tevhid düşüncesini bozacak herhangi bir unsur bulunmayacaktır. Bu sayede ma'dûmun şeyiyyeti ile birlikte taaddud-u kudema endişesine de yer kalmayacaktır.

Mutezilî ma'dûm görüşündeki bu iki hususiyet, İslam kelamındaki ma'dûm tartışmalarının, Allah'ın ezelî ilmi ve tevhidin korunması kapsamında yürütüldügüne işaret ediyor gibi görünmektedir. Bu iki konudaki iki temel kabul üzerine bina edilen ma'dûm görüşü sayesinde Mutezilîler, bir yandan ma'dûmun şeyiyyetinin isbatı ile Allah'ın ilminin kusursuzluğunu ortaya koymayı, bir yandan da ma'dûmun keyfiye-

25 Nîsâbûrî, el-Mesâil, 44. 
tinin bedenî değil zihnî bir mevcudiyet (المعلوم(26 olduğu düşüncesi sayesinde kadîmlerin çokluğu tehlikesinden sakınmayı gaye edinmektedir.

\subsection{Cevherin Yokluk Halinde de Cevher Olmasının Gerekliliği}

Nîsâbûrî̀nin ma'dûm anlayışının temeli, cevherin, hem somut varlık halinde iken hem de bunun öncesindeki maddûm halinde iken yine cevher olduğu kabulüne dayanır. Buna göre cevher, asıl itibarda kadîm ve zâtından dolayı cevher olarak kabul edilmiş olur. Ma'dûmun "şey" olarak kabul edilmesi de aslında onun cevher olması yönüyledir. Bundan dolayı cevherin, yokluk halinde de cevher olduğu sabit kılındığında, ma'dûmun şeyiyyeti de sabit kılınmış olacaktır. Nitekim Ebû Ali el-Cübbai, Ebû Haşim el-Cübbai ve Ebû Abdullah el-Basrî de cevherin, ma'dûm iken cevher olduğunu ileri sürmüşlerdir. ${ }^{27}$

Nîsâbûrî, cevherin, ma'dûm iken cevher olduğunu ortaya koymak üzere detay1 delillere başvurmuştur. Bu delillerin ilkine göre cevher, zâtından dolayı cevherdir. Durum böyle olunca, zât olmaya devam ettiği müddetçe cevherin, cevher olması gerekir. ${ }^{28} \mathrm{Bu}$ cümleden anlaşılacağı üzere ma'dûmun şeyiyyetinin temel gerekçesi, onun cevher olarak kabul edilmesi; bu şeyiyyetin ma'dûma öncesiz bir varlık kazandırmasının gerekçesi ise cevherin, zâtından dolayı cevher olduğunun kabul edilmesidir. O halde Nîsâbûrînnin kanıtlaması gereken asıl unsur, cevherin, başka bir gerekçeden dolayı değil de zâtından dolayı cevher olduğu hususudur. Çünkü bu akıl yürütmedeki ilk önerme budur. Nîsâbûrî, bu durumun farkında olarak cevherin niçin zâtından dolayı cevher olduğunu ortaya koyma gayretine girmiştir. Bu doğrultuda cevherin, cevher oluşu ile ilgili diğer bütün muhtemel seçenekleri değerlendirmiş ve her birinin imkânsızlığını ileri sürmüştür. Sonuçta ise cevherin, zâtından dolayı cevher olmasını tek mümkün seçenek olarak ilan etmiştir. Mu'tezilî ma'dûm görüşünün temel dayanağı olması açısından, cevherin, zâtından başka bir gerekçeyle cevher olma ihtimallerini ve Nîsâbûrî'nin, bu ihtimallerin her birine yönelik geçersizlik gerekçelerini burada aktarmayı gerekli görüyoruz.

Nîsâbûrî̀ye göre cevher, ya varlığından ya hâdis olmasından ya herhangi bir yön üzere hâdis olmasından ya adem olmasından ya herhangi bir yön üzere adem olmasından ya bir mananın varlığından ya bir fail ile olmasından ya zâtında bulunan şeyden ya da zâtından dolayı cevher olmaktan hâlî değildir. ${ }^{29}$ Nîsâbûrî, bu ifadelerden hareketle cevherin, ancak burada siralanan ihtimallerden herhangi biri ile cevher olabileceğini ifade etmektedir. Ardından ise son seçenek dışındaki bütün ihtimallerin imkânsız olduğunu ortaya koymaya çalışmaktadır.

Nîsâbûrîye göre ilk seçenekte yer aldığı şekilde cevherin, varlığı dolayısıyla cevher olması mümkün değildir, çünkü varlık sıfatı tek bir sıfattır. Eğer cevher, var-

\footnotetext{
26 Nîsâbûrî, el-Mesâil, 44.

27 Nîsâbûrî, el-Mesâil, 37.

28 Nîsâbûrî, el-Mesâil, 38.

29 Nîsâbûrî, el-Mesâil, 38.
} 
lığı dolayısıyla cevher olmuş olsaydı, varlıkların hepsinin cevher olması gerekirdi ki biz bunun yanlış olduğunu biliriz. ${ }^{30}$

Nîsâbûrînin bu açıklamasına temel teşkil eden düşünce, varlık ve mahiyetin ayrı şeyler olarak kabul edilmesidir. Nitekim Mutezilî düşüncede varlık ve mahiyet, birbirinin aynı değil, birbirine mugayir olarak değerlendirilmektedir. Bu ayrım, herhangi bir varlık için iki temel niteliği gerektirir. Bunların ilki, bir şeyi, o şey yapan "mahiyet"; diğeri ise o mahiyetin zihin dışındaki varlığı anlamına gelen "varlık"tır. ${ }^{31}$ Mu'tezile'nin, ma'dûmun şeyiyyeti konusundaki görüşü de aslında bu temelden beslenir. Nitekim Mu'tezile, "ma‘dûm şeydir" ifadesini kullanırken, aslında hiçbir zaman var olmayacak olana değil, henüz var olmamış olana "şey" demektedir. Çünkü Mu‘tezile algısında ma‘dûm, mutlak yokluk değil, varlığın zihinde bulunduğu hal veya varlığın zihin dışında bir varlık kazanması öncesindeki "zihinde varlık" hali anlamındadır. İşte Nîsâbûrî de "cevher, varlığından dolayı cevher olamaz" derken aslında mahiyet-varlık ayrılığından hareketle bu cümleyi kullanmaktadır. Bu çerçevede o, varlığın hudûsu karşısında cevherin ezeliyetine işaret etmekte ve bundan dolayı da kadîm olan mahiyetin, hâdis olan var olma niteliğinden kaynaklanamayacağını ifade etmektedir. Bu noktada daha açık olarak ortaya çıkmaktadır ki Mu'tezilî anlayışta veya en azından Nîsâbûrînin düşüncesinde cevherlik, bir varlık kategorisidir ve ma'dûm da mahiyet olması açısından bu kategoriye dâhildir. Burada ma'dûmun mahiyet olması ile kastedilen ise ma'dûm diye özel bir mahiyetin varlığı değil, henüz varlığa kavuşmamış her bir şeyin varlığa kavuşmadan önceki zihinde varlık halinden ibarettir. Burada şunu ifade etmek gerekir ki "zihinde varlık" tabiri, Nîsâbûrînnin bizzat kendisi tarafından kullanılan bir tabir değildir. Bununla birlikte onun, ma'dûmu, ma'lum ile sınırlaması, ma'dûma, zihinde varlık statüsü vermiş olduğu şeklinde anlaşılabilir.

Yukarıda geçtiği üzere cevherin, ne ile cevher olduğu konusunda Nîsâbûrînin değerlendirmeye aldığı ikinci ihtimal, cevherin hudûsa dayandırılması idi. Nîsâbûrî̀ye göre cevherin, hâdis olmasından dolayı cevher olması imkânsızdır. Cevherin hâdis olmasından dolayı cevher olmasının imkânsızlığının gerekçesi, onun, varlığı sebebiyle cevher olmasının imkânsızlığını gerektiren sebep ile aynıdır. Yani bir önceki ihtimal için dile getirilen imkânsızlık gerekçelerinin tamamı, bu ihtimal için de aynı şey söz konusudur. Buna göre hudûs, başlı başına bir sıfattır. Hâdis olmak, bir şeyin sonradan var edilmiş olmasını sabit kılan bir niteliktir. Oysa cevherlik, tıpkı var olmak sıfatında olduğu gibi, bunun ötesinde ve bundan başkadır. Dolayısıyla hâdis olmak niteliği, bir şeyin sonradanlığının gerekçesi olmaya uygundur; ama aynı şeyin bir de cevher olması için yeterli olmaz. O şeyin cevher olması için başka bir hususiyete daha ihtiyaç duyulur. Ayrıca şayet cevher olmak, hâdis olmak ile gerçekleşseydi, bütün hâdis olanların da cevher olması gerekirdi ki bunun doğru olmadığı sabittir. ${ }^{32}$

30 Nîsâbûrî, el-Mesâil, 38.

31 Râzî, el-Muhassal, 48; Alper, "Yokluk Nedir? Seyfeddin El-Âmıdîde Ma'dûm Kavramı Üzerine Bir İnceleme”, 47-48; Özdemir, Allah'in Bilgisinin Ezelîliği ve İnsan Hürriyeti, 135-136.

32 Nîsâbûrî, el-Mesâil, 38. 
Cevherin, cevher olmasının sebebi veya gerekçesi ile ilgili üçüncü ihtimal, cevherin herhangi bir yön üzere hâdis olabileceğidir. Nîsâbûrîye göre cevherin herhangi bir yön üzere hâdis olmasından dolayı cevher olması da mümkün değildir. Çünkü burada kendisine işaret edilecek olan herhangi bir yön yoktur. Bu ihtimal doğru kabul edildiğinde adeta şöyle bir iddiada bulunulmuş olur: "o vecih vâki olduğunda cevher, cevher olur; o vecih vâki olmadığında ise cevher, cevher olmaz." Böyle bir anlayış, beka halinde, cevherin cevher olmasının imkânsızlığını gerektirir. Nitekim beka halinde cevher, herhangi bir yön üzere meydana gelmiş olmaz. ${ }^{33}$

Nîsâbûrî, iki ve üçüncü ihtimallerde cevherin hâdis bir hususiyet olmasının geçersizliği üzerinde durmaktadır. Dolayısıyla bu seçeneklerin değerlendirilmesi noktasında cevherin hakikatinin ne olduğu belirleyici bir etkiye sahiptir. Cevherin hakikati ile ilgili görüşlerin oldukça çeşitli olduğunu ifade etmek gerekir. Antik Yunan düşüncesinde, Aristo'da, İslam felsefesinde ve kelamcılarda cevher kavramını karşılayacak bir içerikle ama birbirinden oldukça farklı hususiyetler eşliğinde cevherin ele alındığı görülmektedir. Bununla birlikte cevherin, "bir şeyin menşei, tabii teşekkülü veya yapısı, nesnelerin hâsıl edildiği madde, tabii cins ve türler", "ne bir konunun yüklemi olan ne de bir konuda bulunan şey", "altta duran, bir şeye temel veya destek teşkil eden şey" gibi tanımlamalarla ele alındığını söyleyebiliriz. ${ }^{34}$

Nîsâbûrî de bu tanımlamalara benzer şekilde cevherin hudûsunu veya hâdis bir yöne nisbetini imkânsız gördügüüü ortaya koymaktadır. Cevherin hudûsunun imkânsızlığı, cevherin, ancak zâtı itibariyle cevher olması sonucunu dayatmaktadır. Bunun bir adım ötesi ise, cevherin, yokluk halinde iken de cevher olması gerektiği yargısıdır. Diğer bir ifade ile cevherin hudûstan veya hâdis bir yöne isnad edilmekten uzak tutulması, onun kıdemine; cevherin kıdemi ise "şey"lerin yokluk halinde iken de cevher olmalarına işaret etmektedir. Bu ise neticede ma'dûmun şeyiyyetini ve ezeliyetini gerektirmektedir.

Cevherin, cevher olmasının sebebi veya gerekçesi konumunda görülebilecek ihtimallerin dört ve beşincisi, cevherin, ademinden veya herhangi bir yön üzere adem olmasından dolayı cevher olması seçenekleridir. Nîsâbûrîye göre cevherin, ademinden ötürü bir cevher olması mümkün değildir. Çünkü ona göre bu durumda cevherin varlık halinde iken cevher olmasının imkânsız olması gerekirdi. Ayrıca şayet cevher, ademinden dolayı cevher olsaydı, adem hali üzere olan diğer her şeyin de cevher olması gerekirdi ki bu imkânsızdır. ${ }^{35}$

Nîsâbûrî, cevherin, adem halinde iken de cevher olmasının gerekli olduğunu ifade edince, bu durumun akla getirebileceği bir ihtimal olarak cevherin, ademi dolayısıyla cevher olması seçeneğini de değerlendirme ihtiyacı hissetmiş gibi görünmektedir. Ancak tıpkı var olma niteliğinde olduğu gibi yok olma niteliğini de cevher

33 Nîsâbûrî, el-Mesâil, 38.

34 İlhan Kutluer, “Cevher”, Türkiye Diyanet Vakfi İslâm Ansiklopedisi (İstanbul: TDV Yayınları, 1993), 7/450; Mu'tezile'nin cevher anlayışı hakkında ayrıntılı bilgi için bakınız: Fethi Kerim Kazanç, Kadı Abdülcebbâr'da Nedensellik Kuramı (Ankara: Araştırma Yayınları, 2014), 164-176.

35 Nîsâbûrî, el-Mesâil, 38. 
olmaya zaid bir hususiyet olarak görmüş ve cevher olma ile adem olmanın "şey" hakkında farklı boyutları ifade ettiğini vurgulamıştır. Bu seçeneğin geçersizliğini pekiştirmek kastıyla yine var olma niteliğinde olduğu gibi cevherin, ademden dolayı cevher olması söz konusu olsaydı, adem sıfatı açısından ortak olduğu her şeyin cevher olmasının da gerekli olacağını dile getirmiştir. Nîsâbûrî, adem halini cevher olmaya zaid bir biçimde ele alınca "cevherlik" bir asıl olma özelliği elde etmiş, bunun karşısında var olmak veya yok olmak ise cevhere ilişen niteliklere tekabül etmiştir. Bu durumda cevherin, ma'dûm iken de cevher olması gerekli hale gelmiştir. Cevher, ma'dûm iken de cevher olduğuna ve onun cevher olmasının adem olması ile doğrudan ilişkisi bulunmadığına göre ulaşılan sonuç yine aynıdır, yani cevher olan ma'dûm, bir "şey"dir ve ezelîdir.

Cevherin, cevher olmasının sebebi veya gerekçesi ile ilgili altıncı ihtimal, cevherin, bir mananın yokluğundan veya varlığından dolayı cevher olması seçeneğidir. Nîsâbûrîye göre cevherin, herhangi bir mananın yokluğundan veya varlığından dolayı cevher olması da mümkün değildir. Çünkü şayet cevher, bir mananın ademinden dolayı cevher olmuş olsaydı, bu mananın, ondan başkasının cevher olması hariç, cevherin cevher olmasının gerekliliğine mahsus olmaması gerekirdi. Bu durumda ise bütün zâtların birer cevher olması gerekirdi ki bunun yanlış olduğunu zaten biliriz. ${ }^{36}$

Nîsâbûrî, bu açıklamasında, herhangi bir mananın varlığından dolayı cevherin cevher olması seçeneğinden önce, herhangi bir mananın ademinden dolayı cevherin cevher olmasının imkânsızlığını ortaya koymaya çalışmaktadır. Ona göre herhangi bir mananın ademinden dolayı cevherin cevher olması imkânsızdır; çünkü bir mananın yokluğu, onu taşımayan her şey için ortak bir nitelik olduğundan, bu mananın yokluğunun, cevherin cevher olmasına mahsus olmaması gerekir.

Ayrıca Nîsâbûrîye göre ademin, kendine özgü niteliğinden dolayı cevherin cevher olmasına sebep teşkil etmesi de mümkün değildir. Nitekim adem, zorunluluğu imkânsız kılar. Örnek olarak biz, irade eden kimsenin ma'dûm bir irade ile irade etmesinin -bu iradenin ademinden dolay1- imkânsız olduğunu biliriz. Ademde ona ortak olan her şeyin, başkasına ait bir sıfatı gerektirmesi de imkânsızdır. Çünkü böyle bir durumda cevher var olduğunda, zâtın cevher olmasını gerektirmekten çıması gerekirdi. Bu tür şeyler, manalarda söz konusu olmaz. ${ }^{37}$

Nîsâbûrîye göre herhangi bir mananın varlığından dolayı cevherin cevher olması da mümkün değildir. Çünkü bu durumda cevher, başka bir manadan dolayı değil, ancak bu manadan dolayı cevher olabilirdi. Yani cevher olmak, ancak bu manaya sahip olmaya özgü bir durum olurdu. Cevherin dışında bir şeyin cevher olmasını değil de cevherin cevher olmasını gerektirmesine özgü olması için bu mananın o cevherde bir hal olması gerekirdi. Hâlbuki biz ancak yer kaplayan bir cevher olması halinde bu mananın o cevhere girebileceğini biliyoruz. Bu durum ise, yer kapla-

36 Nîsâbûrî, el-Mesâil, 38.

37 Nîsâbûrî, el-Mesâil, 38-39. 
yan bir cevher olması konusunda, bu mananın, o cevherde bulunmaya muhtaç olmasını gerektirir. Ayrıca bu mananın bizzat kendisinin var olması konusunda da o zâtın yer kaplayan bir cevher olmasına muhtaç olması gerekir. Bu durum, o ikisinden her birinin diğerine muhtaç olmasını gerektirir. Bu ise aklen imkânsız bir konumdadır. ${ }^{38}$

Nîsâbûrî, herhangi bir mananın varlığından dolayı cevherin cevher olması seçeneğinin imkânsızlı̆̆ını, bu mananın ancak yer kaplayan bir cevherde bulunabilmesinin gerekliliği etrafında açıklamaktadır. Bu durumda mananın varlığı, cevherin varlığı şartına bağlanmış olur. Cevherin varlığı, mananın varlığı için bir ön şart konumunda iken cevherin varlığının, mananın varlığına bağlanması imkânsız olacaktır. İşte bu gerekçeyle Nîsâbûrî̀ye göre bir mananın varlığı, cevherin cevher olmas1nin sebebi olamaz.

Cevherin, cevher olmasının sebebi veya gerekçesi ile ilgili yedinci ihtimal, cevherin, bir fail ile cevher olması seçeneğidir. Nîsâbûrî̀ye göre cevherin, bir fail ile cevher olması mümkün değildir. Çünkü cevher, bir fail ile cevher olmuş olsaydı, failin onu var etmesi ama onu cevher kılmaması sahih olurdu. Eğer bu doğru olsaydı, failin siyahlığı cevher kılması da sahih olurdu. Çünkü bu iki sıfat arasında zıtlık veya zıtlık sayılabilecek bir şey söz konusu değildir. Şayet bu mümkün olsaydı siyah olan cevhere beyazlık hâkim olduğunda o cevherin bu iki durumdan birinden nefyedilmesi ve diğerinden nefyedilmemesi gerekirdi. $\mathrm{Bu}$ ise, cevherin bir yönden ma'dûm bir mevcut olmasını gerektirir ki bu, imkânsızdır. ${ }^{39}$

Nîsâbûrî, cevherin fail ile cevher olmasının imkânsızlı̆̆ını, böyle bir durumda failin inisiyatifi elinde bulunduracak olması gerekçesine bağlamaktadır. Nitekim bu inisiyatif sayesinde, ilgili fail, cevher üzerinde dilediğince tasarrufta bulunabilecek, bu ise cevherin en özel niteliğini, farklılaşmaya konu olan bir konuma sevk edecektir. Böyle bir farklılaşmanın vukuu söz konusu olduğunda da kaybolan yönü itibariyle cevher ma'dûm bir mevcuda dönüşecektir. Ma'dûm olan mevcudun aklen imkânsızlığı, bu seçeneğin de imkânsızlığını göstermektedir.

Cevherin fail ile cevher olması ihtimali, Nîsâbûrî̀nin en detaylı şekilde ele ald1ğ seçenektir. Nitekim bu konuda muarızlarının temel iddiası, cevherin Allah tarafindan cevher kılındığı; diğer bir ifade ile cevherin, faille cevher olduğu şeklindedir. Nîsâbûrî, muhtemelen bu gerekçeyle cevherin faille cevher olması ihtimalini daha kapsamlı bir analize tabi tutmuş, bu seçeneğin geçersizliğinin gerekçesi olarak ileri sürdüğü önermeye karşı yapılabilecek muhtemel itirazları da değerlendirmeye almiştır.

Bu çerçevede şayet bir kimse, "siz niçin cevher, bir fail ile cevher olmuş olsay$\mathrm{d}_{1}$, failin onu var etmesi ama onu cevher k1lmaması sahih olurdu dediniz?" diye sorarsa, Nîsâbûrîyye göre bu kişiye şöyle denir: “Çünkü cevherin, cevher olması konusunda bir etkinin/tesirin bulunması gerekir ve bu etkinin de etkide bulunanın seçi-

38 Nîsâbûrî, el-Mesâil, 39.

39 Nîsâbûrî, el-Mesâil, 39. 
mine tâbi olması gerekir. Şayet cevheri, ona etkide bulunan, cevher kılmış olsaydı, böyle olurdu. Şayet ona etkide bulunan, cevheri cevher kılmış olmasaydı cevher, cevher olmazdı. Şu örnek, söylediğimiz şeyi açıklamaktadır: Söz, bir fail ile haber olarak meydana geldiğinde, failin onu var etmesi veya var etmemesi nasıl sahih ise onu var etmesi ama haber kılmaması da aynı şekilde sahihtir." 40

Nîsâbûrî, burada cevherin faille cevher olmasının niçin imkânsız olduğunu söz örneği üzerinden izaha çalışmaktadır. Buna göre bir sözün haber kılınıp kılınmamas1, o sözün failinin inisiyatifindedir. Nitekim fail, bir sözü meydana getirir ama bunu kimseye duyurmaz ise o sözü var etmiş ama haber kılmamış olur. Bu durum faille meydana gelen sözün haber kılınıp kılınmamasının failin inisiyatifinde olduğunu gösterir. Tıpkı burada olduğu gibi şayet cevher de bir faille cevher olmuş olsaydı, onun cevher kılınıp kılınmaması failinin tercihine nisbet edilirdi. Çünkü cevherin cevherliği, failin ona yönelttiği tesir çerçevesinde gerçekleşmiş veya gerçekleşmemiş olurdu.

Nîsâbûrî, aynı bağlamda bir de ilim örneği üzerinden kurgulanmış bir itirazı gündemine alır. Ona göre şayet şöyle denirse: "ïlim, bir fail ile ilim oluyor değil midir? Bununla birlikte kadim varlığın ilim olarak bizde yarattı̆̆ şeyleri var etmesi ama onları ilim kılmaması doğru olmaz. Bizim için de nazar yoluyla yaptığımız şeyleri var etmemiz ama onları ilim kılmamamız doğru olmaz." Nîsâbûrîye göre bunu söyleyen kimseye şöyle denir: "Biz, "ilim faille ilim olur" diyor değiliz." Bunun üzerine karşı taraf şayet şöyle derse: "Bunu kabul etmeniz gerekir; çünkü siz failin itikad edileni bilmesini ve itikad nevinden yaptığı şeyin bir ilim olmasında etki sahibi olmasını gerekli görüyorsunuz. Oysa failin hali fiilinden dolayı bir hükümde etkili olmaz. Ancak bu fiil bu hükme bir faille bağlı olduğu zaman, o failin hali fiilinden dolayı bir hükümde etkili olur." Bu kez de bunu söyleyen kimseye şöyle denir: "Bu mesele, senin zannettiğin gibi değildir. Bilakis, failin halinin itikadın ilim olarak meydana gelmesi konusunda müessir/etkili olması imkânsız değildir. Bununla birlikte bir yön üzere gerçekleşmiş olması bakımından, ilim, fail ile olmuş olmaz. Yine bu vechin gerçekleşmesi, itikad edileni bilenin fiilinden kaynaklanmasıyla da ilim olmaz."

Nîsâbûrîye göre bu sözlerin ardından muarızlar tarafından bu soruya, "Yüce Allah'ın bu itikadı var etmesi ama onu bir ilim kılmaması doğrudur", şeklinde cevap verilmesi mümkün değildir. Yine "elde edilen bir bilginin, itikad edilen şey olmayacağı" şeklinde bu soruya cevap verilmesi de mümkün değildir. Tıpkı Zeyd'in evde olduğunun bilinmesiyle, onun orada olmamasının da doğru olacağı gibi. Nitekim şayet Zeyd evde bulunmasaydı ve Allah şu anda bizdeki bir bilgi olan bu itikadı yaratmış olsaydı, bu, bir bilgi olmazdı. Bu durumda bazı yönler açısından bu itikadın bulunması ama onun bir ilim olmaması doğru olurdu. Çünkü bu itikad bizde yaratılmış olsaydı ve biz Zeyd'in evde olmadığını takdir etseydik, "bu, bir ilim olmazdı” diyen

40 Nîsâbûrî, el-Mesâil, 39. 
kimsenin sözü hata olurdu. Yine "onun bir ilim olması gerekirdi" diyen kimsenin sözü de hata olurdu. ${ }^{41}$

Nîsâbûrî, ilim örneği eşliğinde, bir şeyin failin takdirine göre değil, kendi hakikat değerine göre değerlendirilmesi gerektiğine vurgu yapmaktadır. Buna göre bir konudaki hükmü belirleyen unsur, o konudaki failin beyanının ötesinde o beyana da kaynaklık edecek olan gerçekliktir. Tıpkı burada olduğu gibi Nîsâbûrîye göre cevherin cevherliği de failin onunla ilgili beyanına değil, kendi zâtına dayandırılmalıdır. Nîsâbûrînin aktardığı bu örneklerin, ele alınan konu ile ne kadar örtüştügünün tartışılabileceğini ifade etmek gerekir. Nitekim üzerinde söz söylenen alan ilahî âlemdir ve koşullar ise ezelîlik çerçevesindeki koşullardır. Ama bu âlemin ve oradaki gerçekleşme koşullarının temellendirilmesi için getirilen örnek, beşerî âlemden ve zaman koşulları kapsamındadır. Dolayısıyla bu örnek anlatımlar çerçevesinde cevherin faille cevher olmasının imkânsızlığını ortaya koyma çabasının güçlü bir yöntem olduğunu söylemek zor görünmektedir.

Nîsâbûrî, cevherin faille cevher olması konusundaki ikinci önermesi ile ilgili olarak dile getirilebilecek muhtemel bir itirazı da gündemine alır. Bu çerçevede ona göre şayet şöyle denirse: "onu var etmesi ama onu cevher kılmaması doğru iken, onu var etmesi ve onu siyahlık kılması niçin sahih olur.” Bunu söyleyen kimseye şöyle denir: "Cevherin bir fail ile cevher olması ve siyahın da bir fail ile siyah olması durumu doğru olunca, artık zât için onun cinsine ait bir sıfat sabit olmamış olur. Böyle bir durumda "zâtlardan herhangi bir zât hakkında sahih olan şey, başka bir zât hakkında imkânsızdır" denilmesi de mümkün olmaz. Durum böyle olunca her zât hakkında, onun cevher olmasının, siyah olmasının veya failin seçimine bağlı olarak bu zâtın iki sıfattan biri üzere meydana gelmesinin sahih olması gerekir." ${ }^{42}$ Bunun üzerine şayet şöyle denirse: “O ikisinden her birinin, diğerinin yerine husûle gelmesi sahih olduğunda, failin, zâtı, her ikisi için de zât kılması nasıl sahih olur?” Bunu söyleyen kimseye şöyle denir: “Çünkü o ikisi birbirlerine zıt değildir ve birbirine zit iki şeyin yerine geçmezler. Bu iş, bu şekilde olunca, kâdir olan varlığın, zâtı, zıt olmayan iki nitelik üzere var etmesinin sahih olduğuna hükmetmek zorunludur. İki zıttın bir araya gelmesi imkânsız olduğundan dolayı, imkânsız olan, ancak iki zıt sıfatın bir araya gelmesi veya o iki niteliğin iki zıttın yerine geçmesidir". ${ }^{43}$

Nîsâbûrî, bu açılamaları ile ikinci önermesinin sıhhatini ortaya koymayı amaçlamaktadır. Buna göre o, cevherin faille cevher olmasının mümkün görülmesi durumunda o failin zâta cevherliği de siyahlı̆̆ı da yükleyebileceğini ifade etmektedir. Böyle bir kabul durumunda yani cevherin faille cevher olduğunun kabul edilmesi durumunda bu failin zâtı hem cevher hem de siyah kılabileceği yönündeki söylemini ise bu iki niteliğin zıt mâhiyetler olmamasına dayandırmaktadır. Diğer bir

41 Nîsâbûrî, el-Mesâil, 40.

42 Nîsâbûrî, el-Mesâil, 40.

43 Nîsâbûrî, el-Mesâil, 41. 
ifade ile şayet cevher faille cevher oluyorsa, bu fail, ilgili zâtı hem cevher hem de siyah kılabilir; çünkü bu iki nitelik birbirini nefyeden nitelikler değildir.

Nîsâbûrî, bu önermesini emir-nehiy bağlamında da değerlendirir ve bu bağlamin cevherlik ve siyahlık örneğindeki gibi olmayacağını vurgular. Buna göre failin, tek bir söz ile bir şeyi hem emir hem nehiy kılmasının doğru olması gerekmez. Çünkü bu iki hüküm, sözün emir olmaması bakımından birbirine zıt iki şeyin yerine geçer. Ancak failin elde ettiği şeyi irade eden olması, bu durumun dışındadır. Yine sözün nehiy olmaması bakımından da bu iki hüküm, birbirine zıt olan iki şeyin yerine geçer. Ancak ona göre failin elde ettiği şeyi kerih gören olması, bu durumun dışındadır. İki sıfat birbirine zıt olacağından, failin bir şeyi hem irade edici hem de kerih görücü olması mümkün değildir. Bundan dolayı bu iki hüküm, iki zıt sıfata istinat edileceği için, failin tek bir söz ile bir şeyi hem emir hem nehiy kılması doğru olmaz. Dolayısıyla bu iki hüküm arasında zıtlık olmaması açısından failin tek bir fiili hasen ve kabih kılmasının doğru olması gerekmez. Çünkü bu ikisi, birbirine zıt iki şeyin yerine geçer. Nitekim hasen, diğer kabih yönlerden arınmış olmakla birlikte, ancak onda bir amaç hâsıl olduğu zaman hasen olur. Kabih ise ancak onda kabih bir yön bulunduğu zaman kabih olur. Hâsıl eden olmadan kabih yönün hâsıl olması mümkün değildir. ${ }^{44}$

Nîsâbûrî, burada cevherin faille cevher olması söz konusu olsaydı, failin zât üzerinde dilediğince tasarrufta bulunabileceği ve bunun da cevherin farklı formlarda meydana gelmesine yol açabileceği ihtimalini, fiillerin hasen ve kabih olmaları örneği üzerinden temellendirmeye çalışmaktadır. Buna göre failin bir şeyi cevher ve siyahlık kılması mümkündür; çünkü bu ikisi iki zıt veya iki zıttın yerine geçen şeyler değildir. Ancak fiilin hasenlik veya kabihliğinde durum böyle değildir. Çünkü ona göre bu ikisi, iki zıttın yerine geçen şeylerdir.

Nîsâbûrî, cevherin ve siyahlığın aslında iki zıt şey olmadığı şeklinde dile getirilebilecek bir itirazı da cevaplamaya çalışır. Ona göre böyle bir itirazı ifade edecek şekilde şayet şöyle denirse: "Cevher, ancak yer kaplayıcı olduğunda cevher olduğuna göre ve siyahlık ise ancak yer kaplayıcı olmadığında siyahlık olduğuna göre, cevherin cevher olarak ve siyahlığın siyahlık olarak birbirinin yerine geçen iki zıt şey olduğunu niçin inkâr ediyorsunuz?" Bunu söyleyen kimseye şöyle denir: "Siyahın siyah olması konusunda onun yer kaplayıcı olmamasını gerektiren bir şey yoktur. O, ancak onunla görüldüğü bu sıfat ile özelleşir. Dolayısıyla siyahlık, bir cevher olarak hâsıl olduğunda, onun, yer kaplayıcı olmayan bir yer kaplayıcı olması gerekmez. Hasen ve kabihin durumu ise böyle değildir. Çünkü bizim hasen dediğimiz şey, onda bir gayenin bulunmasını gerektirir ve onda kabih yönlerden bir yön bulunmaz. Bizim kabih dediğimiz şey ise, kabih yönlerden bir yönün onda bulunmasını kapsar. Bu durumda o ikisinden biri diğerinden ayrılmış olur. Siyahın siyah olması dolayısıyla yer kaplama sıfatının, zıttın yerine geçmeyeceği konusunda şüphe yoktur. O halde

44 Nîsâbûrî, el-Mesâil, 41. 
şayet o ikisi bu şekilde hâsıl olsaydı, tek bir zât için hâsıl olmasıyla iki zât için hâsıl olması arasında fark olmaz ve siyahlığın var olma konusunda cevherle bir arada bulunması imkânsız olurdu." ${ }^{45}$

Nîsâbûrî, yer kaplayıcılık bağlamında cevherin ve siyahlığın birbirinin yerine geçen veya birbirini nefyeden durumlar olmadığını, bir de insanda yer alan duygular örneği üzerinden açıklamaya çalışır. Buna göre şayet bir kimse şöyle derse: "Cevherin yer kaplayıcı olması açısından birbirinin yerine geçen iki zıt şey olan bu iki sıfatın ayrılığının, beyaz olması bakımından beyazın varlığını ve siyah olması bakımından da siyahın, beyazın varlığına engel olmasının doğru olduğunu niçin inkâr ediyorsunuz? İki sıfattan biri engelleyici olursa, birbirine zit olan iki şeyin, birbirinin yerine geçmesi suretiyle, diğeri onu doğrulamaz." Bu kimseye şöyle cevap verilir: "Bu iş sizin zannettiğiniz gibi değildir. Çünkü onun yer kaplayıcı olması, beyazın her durumda beyaz olması bakımından, beyazın varlığını doğrulamaz; bunu ancak siyah olması durumunda doğrular. Dolayısıyla sizin takdir ettiğiniz şey gerekli olmaz. Bu, bizden birinin şöyle demesi konumundadır: Onun canlı olmasının, nefret edici olmasını doğrulaması ve arzulayıcı olmasının ise bunu (nefret edici olmasını) muhal kılması sıfatıyla bizden birinin canlı olması, arzulayıcı olması bakımından zıttın yerine geçer. Bu durum, tıpkı şöyle söylememiz gibidir: "onun canlı olması, ancak nefret edici olmadığında, onun arzulayıcı olmasını doğrular." Onun nefret edici olmasına gelince, "O, onun arzulayıcı olarak hâsıl olduğunu doğrular" denmesi mümkün değildir. İște bu şekilde "zâtın yer kaplaması -siyah olmadığı zaman- beyazın ancak beyaz olması bakımından var olduğunu doğrular" denir. Siyah olduğunda ise onu doğrulaması mümkün değildir. ${ }^{46}$

Nîsâbûrî, bu açıklamalarıyla cevher olmanın ve siyah olmanın birbirinin yerine geçen durumlar olmadığını bir kez daha ortaya koymaya çalışmaktadır. Nîsâbûrînin bu durumu ortaya koyma konusunda bu denli gayret göstermesi, yine cevherin, faille cevher olamayacağını kanıtlamaya yönelik bir hamledir. Nîsâbûrî, bu konuda ısrarcıdır; çünkü hedefi bu seçeneğin de geçersizliğini kanitlayarak ortada tek ihtimal bırakmaktır. Elbette bu ihtimal, cevherin zâtıyla cevher olması seçeneğidir. Cevherin zâtıyla cevher olması seçeneği tek mümkün seçenek olarak kald1ğında ve ma'dûmun da cevher olduğu sabit kılındığında ma'dûmun şeyiyyeti ve ezeliyyeti de sabit kılınmış olacaktır. Kelam ilmi yöntemi açısından değerlendirildiğinde, bu akıl yürütme sürecinde sebr ve taksim metodunun güçlü bir şekilde kullanıldığını ifade etmek mümkündür. ${ }^{47}$

Nîsâbûrî, siyahlık ve cevherliğin farkını pekiştirmek üzere ileri sürülmesi muhtemel bir itirazı daha gündemine alır. Buna göre şayet bir kimse şöyle derse: "Failin siyahlığı cevher kılması niçin mümkün değildir?” Bunu söyleyen kimseye şöyle denir: Çünkü beyaz, siyaha rastladığı zaman, onun siyah olması bakımından, beyazın

45 Nîsâbûrî, el-Mesâil, 41.

46 Nîsâbûrî, el-Mesâil, 42.

47 Hasan Hanefi, “Kelam ilmi'nin Yöntemi”, çev. Nadim Macit, Dini Araştırmalar, 3/8 (2000), 156-157. 
siyahta yok olması ve cevher olması bakımından, siyahın onda yok olmaması gerekirdi. Beyaz siyaha rastladığı zaman beyazın onda bir hal olması gerekir. Hâlin mahallini nefyetmesi ise mümkün değildir. ${ }^{48}$

Cevherin, cevher olmasının sebebi veya gerekçesi ile ilgili sekizinci ihtimal, cevherin, zâtında bulunan şeyden dolayı cevher olması seçeneğidir. Nîsâbûrî̀ye göre cevherin, zâtında bulunan hal üzere cevher olması da mümkün değildir. Nîsâbûrî bu durumun gerekçesini şöyle açıklamaktadır: "Çünkü o, burada kendisine işaret edilen başka bir slfat değildir ki ona, "o, kendiliğinden dolayı cevherdir", denilsin. Nitekim onunla, onun sıfatlarında asıl olan şey murad edilmektedir. Zira bu sıfatın zâta ait olması ve hem adem hem de vücud halinde devam etmesi gerekirdi. Bizim amacimı da budur. Yine onun, kendisi sebebiyle yer kaplayan olması gerekirdi. İste bu, bizim cevher lafzını kullanmakla murad ettiğimiz manadır." ${ }^{49}$

Nîsâbûrî, bu açıklamalarında cevherin ne olduğu ile ilgili kanaatini de iyice açı̆̆a çıkarmaktadır. Bu kapsamda ona göre cevher, hem adem hem vücûd halinde devam eden, bir şeyin sıfatlarında asıl olan ve kendisi sebebiyle var olan şeydir. Bu tanımlamalarda şeyiyyet ve ezeliyyet nitelikleri açık olarak görülmektedir. Buna göre ma'dûmun cevher olduğu ifade edildiğinde, bu nitelikleri de yapısal olarak taşıd1ğı ve dolayısıyla ezelî bir "şey” olduğu ortaya konulmuş olacaktır.

\subsection{Ma'dûmun Ezeliyyet ve Şeyiyyeti}

Nîsâbûrî, buraya kadar saydığı ihtimallerin hepsinin geçersizliğinin ardından ortada kalan tek seçenek olan, cevherin zâtıyla cevher olduğu yönündeki görüşüne alt yapı hazırlamak üzere zâtın, belirgin sıfatları taşıyan bir "şey" olduğunu ortaya koymaya çalışmaktadır. Nitekim cevheri, "bir şeyin sıfatlarında asıl olan yön” olarak gördüğümüzde, aslında cevherlerin ezelde birbirlerinden ayrışmış olmalarının gerekliliğine ulaşırız. Cevherlerin birbirlerinden ayrışmaları için ise onların, kendilerine mahsus ayırt edici sıfatlarla diğer cevherlerden farklılaşan ve bu nitelikleriyle bilinen şeyler olmalarını bekleriz. Nîsâbûrî, bu durumu izah etmek üzere şöyle bir diyalog kurgulamaktadır:

Şayet şöyle denirse: Niçin "sıfat zâta ait olduğu zaman, zât devam ettiği müddetçe sıfatın da hâsıl olması gerekir." dediniz? Bunu söyleyen kimseye şöyle denir: "Çünkü zâta bağlı olan sıfat, illete bağlı olduğunda, sıfat konumundadır. Benzer şekilde illetin hâsıl olmasıyla birlikte illete bağlı olan sıfatın hâsıl olmaması mümkün değildir. Çünkü illetin var olmasıyla birlikte sıfatın zevâlinde, illetin, sıfatla gerekçelendirilmesinin geçersiz kılınması söz konusudur. Böylece sıfat, sadece zâta bağlı olduğunda, zâtın hâsıl olmasıyla beraber sıfatın hâsıl olmaması mümkün olmaz. Bu, şunu açıkça ortaya koyar: Biz bu sıfatı, başka bir sıfatın muktezası ve sadece o sıfata bağlı kıldığımızda, sıfat-ı muktediyenin (gerektiren sıfatın) hâsıl olmasıyla birlikte

48 Nîsâbûrî, el-Mesâil, 42.

49 Nîsâbûrî, el-Mesâil, 42. 
sıfat-ı muktedanın (gereklilik sonucu ortaya çıkan sıfatın) hâsıl olmaması mümkün olmaz." 50

Nîsâbûrî, burada dile getirdikleriyle cevherin cevherliğini tamamen onun zâtına hamletmiş ve onun ayırt edici vasfı olan belli bir sıfat ile diğer cevherlerden ayrıştığını ileri sürmüş olmaktadır. Nitekim ona göre zâta, zât dememizdeki amaç, bilinmesi ve kendisinden haber verilmesinin sahih olmasıdır ve zât, bunun dışına çıkmaz. Bu sayede onun önceden mevcut olduğunun bilinmesi sahih olur. Dolayısıyla onunla ilgili bilgi sayesinde, bilgi ile bilgi olmayan şey birbirinden ayrılır. Bu sebeple bu bilgide, bu bilginin referansının/müteallakının bulunması gerekir. Çünkü şayet bu bilgiye ait bir referans/müteallak olmasayd1, -kendisi ile kendisi dışındaki şeyin, onun sebebiyle birbirinden ayırt edilmesiyle beraber- ilimlerden herhangi bir şey için de bir referansın/müteallakın olmaması gerekirdi. Bu durumdan dolayıdır ki biz, bilginin bir şeyle bağlantılı olmasının sahih olduğuna hükmederiz. Çünkü bu bilgi sebebiyle, o referans/müteallak ile onun dışındakilerin arasında bir fasıl/ayrışma gerçekleşir, yani onlar birbirinden ayrışır. Benzer şekilde bir şey, onun aynıyla ilişkili olduğunda, bu bilgi sebebiyle, onunla, onun dışındaki zâtlar arasında fasıl/ayrışma vâkî olur. ${ }^{51}$

Nîsâbûrî̀ye göre ma‘dûmun ezeli bir şey olması konusunda bir delil de ma‘dûmun iki çeşit olmasıdır. Ma'dûmların ilki, var olduğu takdirde yer kaplayıcı olması gerekli olan malumdur. İkincisi ise var olduğu takdirde yer kaplayıcı olması imkânsız olan malumdur. Bu iki tür malumun farkının belirgin kılınması gerekir. Bundan dolayı her iki malum da gerek sıfat-ı muntazar (henüz vücut bulmamış) gerekse sıfat-1 hâsıla (vücut bulmuş) sıfatlarıyla birbirlerinden ayrışırlar. Onların her birinin s1fat-1 muntazar ile temayüz etmesi mümkün değildir; çünkü ayırt etme konusunda müessir olan şeyin, temyizin/ayırt ediciliğin ona bağlı olmasıyla beraber, o şeyden vazgeçici olması mümkün değildir. ${ }^{52}$

Nîsâbûrî, burada ma'dûmu, malum olanlarla sınırlamıştır. Buna göre ancak bilinebilir olan bir şeyin ma'dûm olması düşünülebilir. Nitekim bilinemeyenin şeyliği söz konusu olmadığından, ma'dûm olması da mümkün değildir. Burada Ehl-i Sünnet ile Mu'tezile’nin görüşlerindeki farklılığın gerekçesinin açığa çıktığını ifade etmek mümkündür. Yukarıda ifade edildiği üzere Ehl-i Sünnet'e göre ma'dûm, mutlak yokluk idi. Nîsâbûrî ise burada ma'dûmu, malum olarak nitelemek suretiyle onun mutlak yokluk değil, henüz var olmamış olan veya var olup da hâl-i hazırda varlığı son bulmuş olanla sınırlı olduğuna işaret etmiş olmaktadır. Mutlak yokluk ise Nîsâbûrînnin gündemine hiç girmemektedir. Nitekim muhtemelen o, bilinmeyen şeyin yokluğundan bahsetmenin dahi mümkün olmayacağını düşünmektedir. Diğer bir ifadeyle yokluk, varlığa nisbet ile söz konusu edilebileceğinden ve mutlak yokluğun, var olmakla hiçbir surette ilişkisi bulunmadığından, mutlak yokluğa ma‘dûm

50 Nîsâbûrî, el-Mesâil, 43.

51 Nîsâbûrî, el-Mesâil, 43.

52 Nîsâbûrî, el-Mesâil, 44. 
denilmesi bile doğru değildir. Buna göre Ehl-i Sünnet'in ma‘dûmdan anladı̆̆ı şey ile Nîsâbûrî özelinde Mu'tezile'nin ma'dûmdan anladığı şey farklıdır. Bu farklılığın detayında ise şunu görmek mümkündür ki Mu'tezile'nin ma‘dûm dediği şey, aslında Ehl-i Sünnet literatüründeki Allah'ın ezelî bilgisinin karşılığıdır. Ehl-i Sünnet'in mutlak yokluk anlamında ma'dûm dediği şeyin ise Mutezilî literatürde hiçbir karşıllı̆̆ yoktur; çünkü Mu'tezile'de Allah'ın bilmediği bir şeyin varlığından veya varlığının muhal olmasına nisbetle yokluğundan bahsetmek mümkün değildir.

Ma‘dûm, bilinebilir olanlardan ibaret görüldüğünde ve Allah'ın bilgisinin her şeyi kuşattığı kabul edildiğinde, bu iki yargının birlikteliğinin ulaştıracağı sonuç, ma‘dûmun ezelîliğidir. Çünkü Allah için her şey ezelde malumdur. Mademki her şey ezelde malumdur, o halde onlar aynı zamanda birbirlerinden ayrışan nitelikleriyle temayüz etmiş olan “şey”ler olmalıdırlar. Nîsâbûrî, bu durumu, Allah'ın, diğer bütün varlıklardan farklılığı ile ilişkili olarak ele almaktadır. Ona göre Allah'ın, kendisi dışındaki her türlü malumdan ayrışmış olması ve onlara benzememesi gerekir. Allah'ın zâtına râci olan konularda hiçbir şeyin onun yerine geçmesi mümkün değildir. Muhalefet/benzememek de zaten budur. Durum böyle olunca ezelde malum olanın kadim varlığa muhalif ve ondan mütemeyyiz/ayrı olması gerekir. Böyle olması ise ancak onun, kendisiyle diğerlerinden temayüz edeceği bir sıfatla özelleşmesi durumunda mümkün olur. Bundan dolayı ma'dûmun, kendisiyle diğerlerinden temayüz edeceği bir sıfat üzere olmasının gerekliliği ortaya çıkar. ${ }^{53}$

Nîsâbûrî, ma'dûmun ezelî ve malum bir "şey” olduğunu, Allah'ın ezelde her şeyi bilmesi açısından da kanıtlamaya çalışır. Ona göre bilinmesi mümkün olan şey, ancak ayrıntıya/tafsil nisbetle malum olabilir. Çünkü malumun ayrıntılı olarak bilinmesi sahih olmadığında icmâlî olarak bilinmesi de sahih olmaz. Bu sabit olunca malumun, ancak kendisiyle diğerlerinden temayüz ettiği bir sıfata istinad etmesi durumunda ayrıntılı olarak bilinmesinin mümkün olacağı anlaşılmış olur. O halde bilinenlerin, bütün durumlarda, kendisiyle diğerlerinden temayüz ettiği sıfatlara istinaden mevcut veya ma'dûm olması gerekir. ${ }^{54}$

Ma‘dûmun ezelî ve malum bir "şey” olduğunu kanıtlamak üzere Nîsâbûrînin ileri sürdüğü diğer bir delil de bilmeden yaratmanın mümkün olmamasıdır. Buna göre Allah Teala, cevheri yaratmak istediği zaman, ancak hâlini bildiği bir şeyi icad etmeye yönelmesi gerekir. Allah'ın icad etmeye yöneldiği bu cevher ile ilgili Allah'ın bildiği hâl ise, vücut bulduğunda onun yer kaplamasının gerekli olacağıdır. Cevher, varlığı halinde diğerlerinden temayüz etmedikçe bu hususlar vâkî olmaz. Bir sifatla özelleşmedikçe de kendisi dışındakilerden temayüz etmesi mümkün olmaz. Buradan hareketle bilinir ki cevher, ma dûm iken de belirgin bir sifat ile temâyüz eden ezelî bir "şey" dir. ${ }^{55}$

Nîsâbûrî, ma'dûmun şeyiyyeti ile ilgili kendi görüşüne ait delilleri bu şekilde aktardıktan sonra muarızların bu görüş ile ilgili itirazlarını gündemine alarak değer-

\footnotetext{
53 Nîsâbûrî, el-Mesâil, 44-45.

54 Nîsâbûrî, el-Mesâil, 45.

55 Nîsâbûrî, el-Mesâil, 45.
} 
lendirir. Bu itirazların ilkine göre şayet cevher, adem halinde cevher, araz da adem halinde araz olmuş olsaydı, Allah Teala'nın herhangi bir araz veya herhangi bir cevher yaptığını söylemek mümkün olmazdı.

Nîsâbûrîye göre bu itiraz geçerli olmaktan uzaktır. Çünkü failin manası, güç yetirilen bir şeyin bulunmasını gerektirir. Allah Teala, cevheri, vücud sıfatına istinaden husûle getirince, arazı da yine vücud sıfatına istinaden husûle getirince, ikisinin faili olmuş olur ve bu soru, soruyu sorana döndürülerek şöyle denir: "sen, ma'dûmu şey olmakla nitelendiriyorsun. Şayet senin zikrettiğin şey doğruysa, senin, "Allah Teala şeylerden hiçbir şeyi var etmemiştir", demen gerekir." Bu cevaba karşllik olarak şayet muarız şöyle derse: "Bu dediğin şey, benim için geçerli değildir. Çünkü Allah, ma'dûmu, ademden vücûda çıkardığı zaman, onu ihdas etmiş olur. İhdasın manası da işte budur. Şayet ma'dûm, ademi halinde bir şey olmuş olsaydı, "bu cevabın bir benzeri bizim için gerekli olur” derdik. Bu dediğiniz, ma 'dûmu malum olmakla nitelendiren ama onu şey olarak isimlendirmeyi imkânsız gören kimse için geçerli olur." Nîsâbûrîye göre bunu söyleyen kimseye şöyle denir: Şayet senin söylediğin doğru ise "Allah Teala, bildiği şeylerden herhangi bir şey yaratmaz" demen gerekir. Çünkü Allah onu yaratmadan önce o malumdu. Öyleyse onun yarattığı şey nedir? Allah'ın yarattığı şey malum muydu yoksa onların bize söyledikleri şekilde malum olmayan mıydı? Onların buna cevap verme konusunda zikrettikleri hiçbir şey yoktur.

Nîsâbûrînnin burada dile getirdiği itiraz ve verdiği cevaplar muhtemelen Mu'tezile'nin Bağdat ekolü ile yürüttüğü bir diyalogu yansıtmaktadır. Nitekim her iki tarafın da ma'dûmu "şey" olmakla nitelediği, ancak onun cevher veya araz oluşunun, ma'dûm ve mevcut hallerindeki durumlarıyla ilgili ayrıntı üzerinde tartışma yürüttükleri görülmektedir. Bu konuda ise Nîsâbûrînin kanaati açıktır. Ona göre cevher, ma'dûm iken de cevherdir; araz ise ma'dûm iken de arazdır. ${ }^{56}$

Nîsâbûrînnin değerlendirmeye aldığı ikinci itiraz şöyledir: Cevherin, var olmasından dolayı cevher olmasına ilave olarak zaid bir sifatı yoktur. "O, her durumda cevherdir." denildiğinde, sanki "o, her durumda mevcuttur" denilmiş gibi olur. Nîsâbûrî̀ye göre bu itiraz, büyük bir hatadır. Çünkü cevherin var olmasından dolayı, cevher olmasına ilave olarak zaid bir sıfatı vardır. Cevherin, faille cevher olmasının imkânsızlı̆̆ının delillendirilmiş olması, bu durumu açılar. ${ }^{57}$

Nîsâbûrînin gündemine aldığı üçüncü itiraz şöyledir: "Şayet ademi durumunda cevherin cevher olması mümkün olsaydı, adem halinde iken cevherin yer kaplayıcı olmasının sahih olması gerekirdi. Yine adem halinde zıtlıkların da mümkün olması gerekirdi. Çünkü cevherle ilgili olarak makul olan, zıtlıkları kabul eden olmasıdır. Biz bunun fasid olduğunu biliriz. Dolayısıyla söylediğiniz şeyin fasit olması gerekir."

Nîsâbûrîye göre bu itiraz, illetsiz bir şekilde iki farklı şeyi bir araya getirmiştir. Bu itirazın fâsid olmasındaki yön, cevherin, ma'dûm halde iken yer kaplayıcı olmas--

56 Nîsâbûrî, el-Mesâil, 45-46.

57 Nîsâbûrî, el-Mesâil, 45-46. 
nın mümkün olmayacağının açıklanmış olmasıdır. Çünkü şayet cevher, adem hâlinde iken yer kaplayıcı olsaydı, ademi halinde görülmesi de gerekirdi ki bu imkânsızdır. Zira cevherin zâtı, -şayet görülseydi- ancak o nitelik sayesinde görüleceği bir sıfat üzere hâsıl olsaydı; yine bizden biri -şayet görseydi- ancak o nitelik sayesinde göreceği bir s1fat üzere hâsıl olsaydı ve engeller de ortadan kalksaydı, işte ancak o zaman onu görmesi zorunlu olurdu.

Cevherin, ma'dûm iken gayr-1 mütehayyız olması sebebiyle idrak edilemeyecek olması çerçevesinde "niçin ma'dûmu idrak etmemiz mümkün değildir" şeklinde bir soru sorulması durumunda ise Nîsâbûrî bu soruya şöyle cevap verilmesi gerektiğini söyler: Biz biliyoruz ki ikinci bir ses vaki olduğunda, ilk ses ile ilgili idrakımız kesilir/sona erer. Bu, onun ademi sebebiyle böyle olur. Adem konusunda ona ortaklık eden her şeyi idrak etmemiz muhaldir. Cevher ma'dûm iken hiçbir şeyin onun yerini alması mümkün değildir. Çünkü şayet siyahlığın, ma'dûm olan cevherin yerini alması doğru olsaydı, siyahlığın, ma‘dûm olan cevherin yerine geçmesi gerekirdi. Ma'dûm olan beyaz için de aynı şey söylenebilir. Şayet böyle bir durum mümkün olsaydı bu, aynı şekilde siyahlık ve beyazlığın tek bir mahalde ve tek bir durumda iki hal olmasını da gerektirir ki bu imkânsızdır.

Nîsâbûrî, ma'dûm görüşünün son kısmında aktardı̆̆ı bu itirazlar ve onlara yönelik cevapları çerçevesinde ma dûmun, ezelî ve gayr-1 mütehayyız bir "şey" olduğu fikrinin aklî bir zorunluluk olduğunu ifade etmiş olmaktadır. Oldukça soyut ve tecrübe dünyamızın çok uzağında bir konu olmasından hareketle Nîsâbûrînnin konuyla ilgili görüşlerinin ve itirazlara yönelik savuşturma çabalarının ne denli aklî bir zorunluluk doğuracağı tartışılır durmaktadır. Bununla birlikte ortaya koyduğu her bir delil ve itirazlara karşı geliştirdiği her bir savunu argümanı ile Nîsâbûrînin ma'dûm anlayışının kendi içinde tutarlı ve belirgin aklî temeller üzerine oturmuş bir ma'dûm görüşü olduğunu söylemek mümkündür. Diğer taraftan benzer gerekçelerle Ehl-i Sünnet'in geliştirdiği ma'dûm anlayışının da Nîsâbûrî özelinde aktarmaya çalıştı̆̆ımız Mu'tezilî ma'dûm anlayışı karşısında benzer şekilde nitelenebileceğini ifade edebiliriz. Diğer bir ifade ile bu konuda herhangi bir yaklaşımı diğerine tercih etmek için nass veya akıl kaynaklı çok güçlü verilerin bulunduğunu söylemek de zor görünmektedir. Esasen yukarıda ifade edildiği üzere bu konudaki ayrılığın kavramlara yüklenen anlamların farklılığından kaynaklanan bir ayrılık olduğunu da ifade etmek gerekir. Nitekim şüphe yok ki Ehl-i Sünnet "ma'dûm, mutlak yokluktur" derken, Allah'ın yarattı̆̆ı şeyleri aslında bilmediğini iddia ediyor değildir. Ancak benzer şekilde tenzihi anlayışı şiar edinmiş bir mezhep olarak Mu'tezile de "ma'dûm, şeydir" derken, Allah ile birlikte ve Allah'tan ayrı ezelî bir varlığın var olduğunu iddia ediyor olamaz. Buradan hareketle diyebiliriz ki Ehl-i Sünnet ile Mu'tezile arasındaki bu tartışma, kavramlara farklı anlamlar yüklemiş olmaktan kaynaklanan lafzî bir tartışmadır. İşin aslında Ehl-i Sünnet Allah'ın ezelî bilgisinin kusursuzluğundan ödün vermediği gibi Mu'tezile de tevhid ilkesinden vaz geçmiş değildir. 


\section{Sonuç}

Ma‘dûm, Allah'tan başka bütün varlıkların, ihdas edilmelerinden önce mutlak anlamda yok oldukları veya varlıksal bir hüviyete sahip olarak, bir şekilde var oldukları çerçevesinde yürütülen klasik dönem Kelam tartışmalarından birini ifade eder. Bu tartışma dâhilinde Ehl-i Sünnet, ma'dûmun mutlak yokluk anlamında "hiçbir şey” olduğunu savunurken; Mu'tezile, ma'dûmun mutlak yokluk olarak nitelenemeyeceğini, aksine "şey” olduğunu ileri sürmektedir. Ma‘dûm konusundaki bu iki kanaat, Ehl-i Sünnet'ten veya Mu'tezile'den olmanın belirleyici özelliklerindendir. Ehli Sünnet'in ma'dûm anlayışı, Sünnî düşünürlerin kendi eserleri üzerinden detaylı olarak ele alınıp incelenmiştir. Ancak Mu'tezile'nin ma'dûm görüşü Mu'tezilî düşünürlerin eserleri üzerinden değil de daha çok yine Sünnî düşünürlerin eserlerinde haber verilen Mu'tezilî malumattan hareketle değerlendirilmiştir. Bir mezhebin herhangi bir konudaki kanaatinin, muarızların aktarımları üzerinden anlaşılması, ilgili kanaatin yanlı veya gereğince anlaşılmadan sunulması gibi ciddi sorunları beraberinde getirebilmektedir. Mu'tezile'nin ma'dûm hakkındaki yaklaşımı konusunda böyle bir durumun vâki olduğunu ifade etmek mümkündür. Nitekim Mu'tezile'nin kendi kaynakları üzerinden yapılan bu çalışmada onların ma'dûm anlayışının önemli bazı noktalarda gereğince anlaşılamadı̆̆ı veya yanlış anlaşıldı̆̆ı görülmüştür.

Ebû Reşî̀d en-Nîsâbûrî özelinde Mu'tezile’nin ma'dûm anlayışının kendi kaynakları çerçevesinde ele alındığı bu çalışmada öncelikle ortaya çıkan husus, Mu'tezile'nin tek tip bir ma'dûm anlayışına sahip olmadığı ve ma'dûm konusunda kendi içinde başlıca iki gruba ayrıldığıdır. Bu ayrılığın odak noktası, ma‘dûmun mütehayyız veya gayr-1 mütehayyız olmasıdır. Nîsâbûrînin bildirdiğine göre bu ayrılık içinde ma'dûmun mütehayyız olduğu düşüncesi Bağdat ekolü tarafından savunulurken; gayr-1 mütehayyız olduğu düşüncesi ise kendisinin de dâhil olduğu Basra ekolü tarafından savunulmaktadır. Ma'dûmun gayr-1 mütehayyız olduğunun ortaya konulma çabası, aslında Mu'tezile'nin ma‘dûma somut bir varlık atfetmeme kaygıs1nı yansıtmaktadır. Bunun karşısında ma'dûmun bir "şey" olduğu yönündeki ssrarlar1 ise Allah'ın bilmediği bir şeyin olamayacağı ve bilmediği bir şeyi yaratmış olmaması gerektiği kaygılarını yansıtmaktadır. Mu'tezile'nin ma‘dûm ile kastettiği mananın bu çerçevede anlaşılması gerekmektedir. Buna göre Mu'tezile açısından ma'dûm, varlıkların ihdas edilmesinden önceki yokluğu temsil eden somut bir varlık değil, tabiri caizse varlıkların, Allah'ın zihnindeki öncesel sûretleridir. Diğer bir ifade ile ma'dûm, ihdas edilecek olanların, ne olarak ihdas edileceklerine dair Allah'ta bulunan bir bilgiden ibarettir. Nitekim Nîsâbûrî, ma'dûmu, malum olarak tanımlamış ve malumdan başka ma'dûmun bulunmadığını ifade etmiştir. Böyle bir tanımlama, Mu'tezile'nin ma'dûm anlayışının, Allah'ın ezelî bilgisi kapsamında şekillendiği izlenimini uyandırmaktadır. Bu ise, doğrudan Ehl-i Sünnet'in, Allah'ın ezelî bilgisi hakkındaki görüşünü çağrıştırmaktadır. Nitekim karşılaştırmalı olarak ele alındığında Mu'tezile, Allah'ın her şeye ilişkin bilgisini ma‘dûm olarak isimlendirmekte ve bu- 
nun, Allah'ın ezelî bilgisinde yer aldığını ileri sürmekte; o kadar ki ma‘dûmu "şey" olarak nitelendirmektedir. Ehl-i sünnet ise Allah'ın ezelî bilgisi ile var olacak olan her şeyi, var olacakları sûret üzere ezelde bildiğini ifade etmekte; o kadar ki ma'dûmu "şey" olarak değil "mutlak yokluk" olarak nitelendirmektedir. Bu duruma göre anlaşılan odur ki Mu'tezile ile Ehl-i Sünnet içerik itibariyle aynı düşünceyi savunuyor olmakla birlikte kavramlara yüklemiş oldukları anlam itibariyle muarı gibi görünmektedir. Hâlbuki bu tartışmalarda her iki tarafın da kaygısı aynıdır. Bu kaygı, Allah’ı ezelde her türlü şerikten uzak tutmak ve Allah'ın bilgisini her türlü eksiklikten münezzeh kılmaktir.

Nîsâbûrî, her ne kadar yer kaplayıcı olmasa da ezelde her bir cevherin ayırt edici bir sıfat ile zâtı itibariyle diğer cevherlerden ayrışmış bir "şey" olarak nitelenmesi gerektiği kanaatindedir. Buna göre ma'dûm, ezeliyyet ve şeyiyyeti bulunan bir malumdur. Nîsâbûrîye göre ma'dûmun ezeliyyet ve şeyiyyetinin birçok delili bulunmaktadır. Bu delilleri şöyle sıralamak mümkündür:

- Cevher, zâtıyla cevherdir. Zât denildiğinde ise belirgin bir vasfı olan ve bu vasfı ile bilinip kendisinden haber verilen şey kastedilir. Bir şeyin bilinmesi ve kendisinden haber verilmesi için ise onu, diğer bilinenlerden ayıran, ayırt edici vasfının bulunması gerekir. Cevherin cevher oluşu, onun zâtından kaynaklandığına göre her bir cevherin, onu diğerlerinden ayıran bir vasfı bulunmalıdır. Cevher zâtıyla cevher olduğuna ve ayırıcı bir vasıf ile ayrışmış olduğuna göre o, mevcut iken de ma'dûm iken de cevherdir, yani bilinen ve kendisinden haber verilen bir "şey"dir.

- Ma‘dûm, mütehayyı malum ve gayr-1 mütehayyı malum olmak üzere iki çeşittir. Bunların ikisinin birbirinden ayırt edilebilmesi için belirgin bir sıfat ile ayrışmaları gerekmektedir. O halde ma'dûm, kendisinden ayrılması mümkün olmayan sıfat ile ayrışan zât olarak ezelî bir "şey” hüviyetine sahip olmalıdır.

- Malum olan şeyin, Allah'ın ezeldeki zâtından ayrı bir şey olması gerekir. 0 halde her malumun, hem ma'dûm hem de vücud halinde iken bariz sifatlariyla ayrışmış bir "şey" olması gerekir.

- Bir şey, ancak ayrıntısına vâkıf olunduğunda malum olur. Mademki Allah ezelde her şeyi bilmektedir; o halde her şeyin ayrıntısına da vâkıf olmalıdır. Malum, ancak diğerlerinden ayrışan bir vasıfla bilinebildiğine göre, bilinenlerin tamamı, kendilerini diğerlerinden ayıran ayırt edici vasıflarla malum veya ma'dûmdurlar. Buna göre ma'dûm da olsa her malum, ayrışmış vasfı ile bilinen bir "şey"dir.

- Allah, bir şeyi yaratmak istediğinde, ancak onu bilmesi durumunda yaratabilir. Buna göre Allah'ın yarattığı her şeyin Allah tarafından bilinmesi gerekir. Allah'ın bilgisi ezelî ve değişmez bir bilgi olduğuna göre ayrışan sıfatlarıyla birlikte her şey, ma'dûm iken de Allah'a malum olan bir "şey"dir.

Nîsâbûrî, bütün bu deliller ile ma'dûmun keyfiyetine dair görüşünü belirgin hale getirmektedir. Buna göre Nîsâbûrî özelinde Mutezilî ma‘dûm anlayışının te- 
mel dinamiklerinden ilki, ma‘dûmun cevher olarak kabul edilmesidir. Nîsâbûrîye göre cevher, zâtıyla cevher olduğundan onun bir başlatıcısı da yoktur. O halde ma‘dûm, ezelî bir cevherdir. Buna ilave olarak Allah'ın bilmediği bir şey olamayacağına göre ma‘dûm, ezelî bir cevher olarak Allah katında malumdur. O kadar ki henüz hudusa konu olmadığından o, somut bir varlık değil, zihinde varlık olarak malumdur. Ma'dûm, mademki malumdur, o halde onun bilinmesini sağlayan ayırt edici bir sıfat ile diğer cevherlerden ayrışmış olması gerekir. Belli bir sıfat ile diğer cevherlerden ayrışan bir şeyin var olmadığı söylenemez. Bundan dolayı ma‘dûm, ancak bilinen ve kendisinden haber verilen bir "şey" olarak tanımlanır. Bu "şey"in varlığı, Allah'a rağmen veya Allah'tan gayrı bir varlık değil, aksine Allah'ın bilmesi bağlamında Allah'ta olan bir varlıktır.

Etik Beyan / Ethical Statement

Yazar / Author
Bu çalışmanın hazırlanma sürecinde bilimsel ve etik ilkelere uyulduğu ve yararlanılan tüm çalışmaların kaynakçada belirtildiği beyan olunur/It is declared that scientific and ethical principles have been followed while carrying out and writing this study and that all the sources used have been properly cited.

Muzaffer Barlak

\section{Kaynakça}

Afifî, Ebû'l-Alâ. "Mu'tezile'nin Ma‘dûm Nazariyesi İle İbn Arabînin A'yân-1 Sâbite Nazariyesinin Karşılaştırılması”. çev. Cağfer Karadaş. Uludağ Üniversitesi İlahiyat Fakültesi Dergisi 6/6 (1994), 267-276. https://doi.org/10.1501/ilhfak_0000001067

Alper, Hülya. "Yokluk Nedir? Seyfeddin El-Âmidîde Ma‘dûm Kavramı Üzerine Bir İnceleme”. İstanbul Üniversitesi İlahiyat Fakültesi Dergisi 28 (2013), 33-58. https://doi.org/10.21054/ deuifd. 493129

Âmidî, Seyfüddin. Ebkâru'l-Efkâr fî Usûli'd-Dîn. thk. Ahmed Muhammed el-Mehdî. Kahire: Dâru'l-Kütüb ve'l-Vesâiki'l-Kavmiyye, 2004.

Bâkıllânî, Ebû Bekr. Kitâbü Temhîdi'l-Evâil ve Telhîsü'd-Delâil. nşr. İmâdüddîn Ahmed Haydar. Beyrut: Müessesetü'l-Kütübi's-Sekâfiyye, 1993.

Cüveynî, İmâmu'l-Harameyn. eş-Şâmil fî Usûli'd-dîn. thk. Ali Sâmi en-Neşşâr, Süheyr Muhammed Muhtâr, Faysal Bedir Avn. İskenderiye: Münşeetü’l-Maârif, 1969.

Frank, R. M. "Al-Ma'dūm wal-Mawjūd the Non-Existent, the Existent and the Possible in the Teaching of Abū Hāshim and His Followers". Mélanges Institut Dominicain D'études Orientales (MIDEO) 14 (1980), 185-210.

Hanefi, Hasan. “Kelam İlmi'nin Yöntemi”. çev. Nadim Macit. Dini Araştırmalar 3/8 (2000), 149161.

İbn Fûrek, Ebû Bekr Muhammed. Mücerradü Makalâti'ş-Şeyh Ebi'l-Hasan el-Eşsarî. nşr. Daniel Gimaret. Beyrut: Dârü'l-Maşrık, 1986.

İbn Manzûr, Lisanü'l-Arab. thk. Abdullah Ali Kebir, Muhammed Ahmed Hasbullah, Haşim Muhammed Şazeli. Kahire: Dâru'l-Maarif, ts. 
Kâdî Abdülcebbâr, Ebu'l-Hasan el-Hemedânî. El-Muhît bi't-Teklif. Thk. Ömer es-Seyyid Azmî. Kahire: eş-Şeriketü'l-Mısriyye, ts.

Kâdî Abdülcebbâr, Ebu'l-Hasan el-Hemedânî. Şerhu'l-Usûli'l-Hamse. thk. Abdulkerim Osman. Kahire: Mektebetü Vehbe, 1996.

Kahraman, Hüseyin. "Ma‘dûmun Şeyiyyeti Teorisine Cüveynînin Getirdiği Eleştiriler Ve Bunların Eş‘arî Kelâmı Açısından Değerlendirilmesi”. Kelâm Araștırmaları Dergisi 14/2 (2016), 443-459. https://doi.org/10.18317/kader.43845

Kazanç, Fethi Kerim. Kadı Abdülcebbâr'da Nedensellik Kuramı. Ankara: Araştırma Yayınları, 2014. https://doi.org/10.18317/kader.11952

Koloğlu, Orhan Şener. Mu'tezile'nin Felsefe Eleștirisi Harezmli Mutezili İbnüll-Melâhimînin Felsefeye Reddiyesi. Bursa: Emin Yayınlar1, 2010. https://doi.org/10.12730/13091719.2010.12.18

Kutluer, İlhan. "Cevher”. Türkiye Diyanet Vakfi İslâm Ansiklopedisi. 7/450-455. İstanbul: TDV Yayınları, 1993.

Mâtürîdî, Ebû Mansur Muhammed. Kitâbü't-Tevhîd Tercümesi. çev. Bekir Topaloğlu. İstanbul: İsam Yayınları, 2005.

Nîsâbûrî, Ebû Reşîd, el-Mesâil fil-Hılâf Beyne'l-Basriyyîn ve'l-Bağdâdiyyîn. thk. Ma'n Ziyâde, Rıdvan es-Seyyid. Beyrut: Ma'hedü'l-İnmâi'l-Arabî, 1979.

Özdemir, Metin. Allah'in Bilgisinin Ezelîliği ve İnsan Hürriyeti. İstanbul: İz Yayıncıllk, 2003.

Râzî, Ebû Abdillâh Fahreddin. Ana Meseleleriyle Kelâm ve Felsefe el-Muhassal. çev. Eşref Altaş. İstanbul: Klasik Yayınları, 2019.

Taşcı, Özcan. Son Mu’tezile Kelamcısı Takiyyüddin Necrânî. Bursa: Sentez Yayınları, 2013.

Wisnovsky, Robert. “íbn Sînânın Şey iyye Kavramı Üzerine Notlar”. çev. Arzu Meral. Marmara Üniversitesi İlahiyat Fakültesi Dergisi 26/1 (2004), 85-118.

Yavuz, Yusuf Şevki. "Ebû Reşîd en-Nîsâbûrî”. Türkiye Diyanet Vakfi İslâm Ansiklopedisi. 10/212213. İstanbul: TDV Yayınları, 1994.

Yıldırım, Ömer Ali. "Ma‘dûm ve Mümkün: Mûtezile’nin “Ma‘dûm” ve İbn Sînâ’nın “Mümkün” Kavramı Üzerine Değerlendirmeler”. İslâm Araştırmaları Dergisi 30 (2013), 81-107. 